\title{
Examination of User Experiences and Needs for the Web Page and Learning Environment Used by Students with Special Needs in Open and Distance Learning: The Case of Anadolu University *
}

\author{
Muhammet Recep OKUR ${ }^{* *}$ Hakan KILINÇ⿻*
}

Gizem YILDIZ $^{* * * *}$

\begin{abstract}
E-learning systems with its flexible structure offer learning environments independent of time and place for students with special needs. The effectiveness of these environments for students with special needs depends on the creation of designs that consider their individual needs. The aim of this research is to reveal the needs, difficulties, and solution suggestions by determining the user experiences for the "e-Campus" system as the web page of the Anadolu University Open Education System "Barrier-Free Open Education Faculty (OEF)", which provides services to most university students with special needs in Turkey, and the online learning environment. For this purpose, a case study design, in which qualitative and quantitative data collection techniques are used together, was used. A total of 9533 students, including 9513 students with special needs and 20 visually impaired students, participated in the quantitative stage of the study. According to the findings of the research, students with special needs reported that the web page and e-Campus system they use are easy to use, they can easily find the content they are looking for, they can access other services from the web page and offer useful content. On the other hand, difficulties in using the mobile application login screen, accessing the call center, and accessing some content on the e-Campus were mentioned among the issues encountered. The visually impaired participants requested support for facilitating access to live lectures, enlarging the texts in online exams, and giving additional time, adding voice prompts to the entry page, and increasing audio narrations. In line with these supports required by the participants and the literature, solution suggestions to overcome the difficulties were discussed.
\end{abstract}

Keywords: Open and distance education, student with special needs, user experience, online accessibility.

\footnotetext{
${ }^{*}$ Ethics committee approval for this study was obtained from Anadolu University Social and Human Sciences Scientific Research and Publication Ethics Committee, dated 03/11/2020 and protocol number 60323.

** Orcid ID: https://orcid.org/0000-0003-2639-4987, Assoc. Prof. Dr., Anadolu University, Turkey, mrokur@gmail.com

*** Orcid ID: https://orcid.org/0000-0002-4301-1370, Dr., Anadolu University, Turkey, hakankilinc@anadolu.edu.tr

**** Orcid ID: https://orcid.org/0000-0003-2693-6264, Dr., Anadolu University, Turkey, 88.gizemyildiz@gmail.com
} 


\section{INTRODUCTION}

Students with special needs define students who differ significantly from their peers in terms of educational qualifications due to their developmental and individual characteristics. This group includes individuals with hearing impairment, visual impairment, physical disability, developmental disability, chronic disease, and other disabilities (Heward et al., 2006). Students with special needs, whose inadequacies often turn into obstacles in the education process, can overcome many obstacles with this elearning system, independent of time and space, which looks out for online learning dynamics with an understanding of openness in education. Anadolu University has been making education accessible to millions of students with its open and distance education system since 1982. Open Education System designs learning environments accessible to all students by using the flexible and individualizable structure of e-learning systems. This situation is important for students with special needs, and one of the target groups of Anadolu University's open and distance education system is students with special needs.

All educational materials prepared in the student-centered learning process in Anadolu University Open Education System are designed for students to learn independently (Sönmez, 2016). Learning-teaching processes in special education are similarly studentcentered, and materials, methods and techniques, and content are individualized according to student needs. In this direction, Anadolu University Open Education System aims to provide services according to students' disability groups and needs with special needs. This situation can be clearly seen because the system that started with "flexible learning" continues with the "intelligent, flexible learning" model today. Flexible learning is a learning system in which different options are created to individualize the learning process in line with the personal needs and preferences of the learners (Demetriadis \& Pombortsis, 2007; Güler, 2018). The dimensions of flexibility are stated by Casey and Wilson (2005) as follows; time, content, entry requirements, learning approach, and resources, logistics, and distribution.

A successful flexible learning system should include systematic planning, design, development, and evaluation steps in order to create an environment in which learning is actively supported (Güler, 2018). The development and evaluation step refers to actively updating and monitoring the process, identifying and fixing problems, and restructuring. Evaluating the learning process serves to monitor, record data, see progress, identify problems, and improve efforts. Accordingly, the development of the learning process of the Open Education System can be evaluated by the users and stakeholders of the system.

These development and evaluation steps are much more important for students with special needs. In fact, the evaluation of the Open Education System by its users can be measured by parameters such as accessibility, user-friendly design, well-structured content, learner-centered approach, and affordable price (Güler, 2018; Khan, 2003). On the other hand, it is known that these parameters can be much more important for 
students with special needs compared to students with normal development (Edyburn, 2001; Özgüç \& Cavkaytar, 2014; Sani-Bozkurt, 2017). Therefore, determining the user experiences, needs, preferences, and difficulties play a critical role in enabling students with special needs to effectively benefit from the Open Education System.

User experience refers to all situations in which the product or service is associated with the user through the interface (Hassenzahl, 2014; Özarslan, 2016). Today, services offered through the interfaces of web pages are mostly used by users. The presentation of products or services alone is no longer sufficient, and the users' experiences, such as their feelings and thoughts, have become the subjects dealt with by the designers to meet the users' wishes and needs. As a result, all of the perceptions that occur when a person interacts with a product or service are considered user experiences (Kuniavsky, 2010; Özarslan, 2016). The user experience, in the end, is ease, accessibility, efficiency, and benefit of the use of a targeted service that is liked by the user. Positive user experiences are often not noticed in the services received while the needs are met but are experienced again when necessary (Baird \& Fisher, 2005; Kuniavsky, 2010; Özarslan, 2016). However, a negative user experience is remembered for a long time, shared with other users, and affects subsequent preferences. Therefore, user experience is very important in order to create sustainable user satisfaction and ensure that services reach their goals effectively and efficiently (Özarslan, 2016). When it comes to services where individuals with special needs are users, the user experience becomes more individual.

Individuals with special needs have special needs depending on their disability. Therefore, it is possible to say that the user experiences of these individuals are also specialized compared to other segments of society (Henry et al., 2014; Rosa \& Valentim, 2020; Yusril, 2020). This situation makes it necessary to design the services to be provided specifically for them. In this context, the design of digital learning environments used by individuals with special needs should be developed according to the type of disability, individual differences, and needs of individuals. In the related literature, studies examining the user experiences of learners in e-learning environments (Emre, Akadal, \& Gülseçen, 2018; Küçükönder \& Kır, 2014; Mutlu, 2015; Sözer, Özdamar \& Pilancl, 2020) emphasizes the importance of benefiting from their experience. At this point, it is stated that Web sites that fulfill the function of sharing information with users need to refer to user experiences in order to be usable and to provide the right answers to the needs of users (Durmuş and Çağlltay, 2012; Emre et al., 2018). On the other hand, there are limited studies on how students with special needs use e-learning systems, what kind of support they need, and how special e-learning environments should be. Studies carried out on this subject emphasize that accessibility is not limited to following technical standards and guidelines, e-learning is much more than technology, and that universal learning-instructional design principles should be taken into consideration by making use of user experiences in e-learning for individuals with special needs (Bühler and Fisseler, 2007; Petrie et al., 2006; Santos, Couchet \& Boticario, 2009; Yusril, 2020). In addition, it is recommended to employ consistent 
assessment methodologies that include all individuals with and without special needs when evaluating accessibility and usability in the e-learning process (Cooper, Colwell, \& Jelfs, 2007). In a study examining the user experience elements of individuals with special needs, it was stated that the usability of products and services depends on the design of these services according to individual characteristics and needs (Lee et al., 2015). In another study conducted on students with special needs (with visual impairments) to use learning systems, it was emphasized that accessibility, usability, and user experience elements are important factors to increase the quality of learning systems. Thus some elements such as screen size, button shapes, color intensity can be improved more (Rosa \& Valentim, 2020).

Schrepp et al. (2017) emphasized that referring to user experiences is applicable for different user groups to be more efficient. At this point, it was also underlined that the tools used in applying for user experiences should be suitable for the target audience in terms of language and level of understanding. In addition, it has been stated that in order for a Web site to be accessible, it should also appeal to individuals with special needs. In addition, in a study conducted by King, Evans, and Blenkhorn (2005), it was emphasized that the usability of Web sites is a very important point for individuals with special needs. The basic pillars of usability are effectiveness, efficiency, and satisfaction (ISO, 2000). Herein, in a study conducted by Okur and Demir (2019), it was stated that the usability of the systems that individuals with special needs (with visual impairment) use in the learning process, such as the Web site, should be examined, and at this point, user experiences should be consulted in order to determine the needs of the users.

As stated in both special education and open and distance education literature, the main thing in the education of students with special needs is the individualization of the learning process (Carneiro et al., 2015; Cho, 2021; Park et al., 2016; Yusril, 2020). Determining the experience of using the system of students with special needs in the Open Education System, identifying the problems they experience while using the system, describing the current state of the functioning system, and revealing the needs and preferences of students with special needs for using the system show themselves as a necessity in terms of both observing the education rights of students with special needs, improving field practices and evaluating the "flexible learning" process, which is the basic principle of the Open Education System. However, considering that as of the 2019-2020 academic year, the number of students with special needs studying at higher education in Turkey is 51,647, and 38,302 of them are registered at Anadolu University (YÖK, 2021), it can be stated that the results to be obtained from this study are that of students with special needs is also important in terms of determining the status of being able to use learning systems and identifying and eliminating the negativities experienced. Since the services most frequently used by students with special needs registered at Anadolu University are the "Barrier-Free OEF" web page and the "ANADOLUM e-Campus System", the user experiences of these systems are discussed within the scope of the study. 
In this direction, the study's main purpose is to determine the user experiences of the students with special needs registered in Anadolu University Open Education System regarding the Accessible OEF web page and e-Campus system. Within the scope of this main purpose, it aims to determine the support needs and difficulties of the users and produce solutions to meet these needs. Solution proposals were created on the basis of research findings and literature. In this direction, answers to the following questions are sought:

1. What are the user experiences of students with special needs regarding the Barrierfree OEF web page?

2. What are the user experiences of students with special needs regarding the e-Campus system?

3. What are the solutions for the difficulties experienced by the students with special needs in the Barrier-free OEF web page and e-Campus system?

\section{METHOD}

\section{Research Design}

In this research, a case study design was used to determine the user experiences, difficulties and support needs of students with special needs registered in Anadolu University Open Education System regarding the barrier-free OEF web page and ANADOLUM e-Kampus system. The case study design refers to the in-depth investigation of a situation. An institution, a program, a service, a system can be examples of situations (Mills \& Gay, 2016; Yıldırım \& Şimşek, 2013). However, in this design, an in-depth examination of that system is provided by using multiple data collection to collect systematic information about how a system operates and works (Chmiliar, 2010). In this study, using the system by students with special needs enrolled in the Open Education system is described by employing quantitative and qualitative data collection techniques. In this context, the user experiences of the students with special needs regarding the Barrier-free OEF web page and the e-Campus system, the difficulties they experience, and the support they need are explained. Solution proposals were created in accordance with the findings obtained from the participants in semistructured interviews and the literature.

\section{Participants}

Ethics committee approval for this study was obtained from Anadolu University Social and Human Sciences Scientific Research and Publication Ethics Committee, dated $03 / 11 / 2020$ and protocol number 60323 . The study group of the research consists of students with special needs registered in Anadolu University Open Education System. Participants were determined from this study group with the purposeful sampling technique. Sample selection, which is thought to provide in-depth information about the researched situation and can provide the most support in answering the research questions, is defined as purposive sampling (Creswell, 2014). Participants were selected 
by criterion sampling, which is one of the purposeful sampling types. Criterion sampling, on the other hand, is a purposeful sampling type in which the features that are predetermined for the purpose and important for the study are determined as criteria, and situations that meet all of these criteria are selected (Merriam, 2013; Ylldırım \& Şimşek, 2013).

In the quantitative data collection dimension of the study, the population of the research is all university students with special needs in Turkey. From this population, all students with special needs registered in Anadolu University Open Education System were selected with purposive sampling in line with the purpose of the research. Among this sample, a total of 9513 students with hearing impairment, visual impairment, physical disability, chronic disease, and other types of disability participated in the survey with criterion sampling. The criteria considered in the selection of the participants in the quantitative dimension are that the participant has any disability (diagnosis) and is an Open Education student.

In the qualitative phase of the research, to collect in-depth information, data were collected from students with visual impairment, who had the most difficulty due to vision impairment in distance education conducted at the screen and the most crowded group in the sample ( $\mathrm{f}=723$ ). 20 visually impaired open education students who were selected by criterion sampling from the research population participated in the qualitative stage. The criteria for forming the sample at the qualitative stage were determined as having $80 \%$ or more visual impairment and being an open education student. In determining this criterion, it has been taken into account that if the degree of visual impairment is high, more probable problems will come to the fore. Thus, it is foreseen that the needs and difficulties will be determined more clearly, and solution proposals will be presented comprehensively. In addition to 9513 students with special needs who participated in the quantitative stage and 20 visually impaired students who participated in the qualitative stage, 9533 students with special needs participated in this research. Demographic information of 9513 students who participated in the quantitative stage is presented in Table 1 . Accordingly, the ages of the participants ranged from 18 to 65 and over, $43 \%$ of them are female, $57 \%$ of them are male, $8 \%$ of them have a visual impairment, $3 \%$ of them have a hearing impairment, $4 \%$ of them have a physical disability, $4 \%$ of them have a chronic disease, and $81 \%$ of them are in the other disability group. 
Table 1

Demographic Information of Quantitative Stage Participants

\begin{tabular}{|c|c|c|}
\hline Variables & Frequency & Percent \\
\hline \multicolumn{3}{|l|}{ Graduation } \\
\hline Doctorate & 44 & 1 \\
\hline Master's degree & 473 & 4 \\
\hline Bachelor's degree & 5458 & 58 \\
\hline High school & 3538 & 37 \\
\hline Total & 9513 & 100 \\
\hline \multicolumn{3}{|l|}{ Program Type } \\
\hline Associate degree program & 5433 & 57 \\
\hline Undergraduate program & 4080 & 43 \\
\hline Total & 9513 & 100 \\
\hline \multicolumn{3}{|l|}{ Type of disability } \\
\hline Visual impairment & 723 & 8 \\
\hline Hearing impairment & 318 & 3 \\
\hline Physical disability & 348 & 4 \\
\hline Chronic disease & 399 & 4 \\
\hline Other disabilities & 7725 & 81 \\
\hline Total & 9513 & 100 \\
\hline \multicolumn{3}{|l|}{ Gender } \\
\hline Female & 4047 & 43 \\
\hline Male & 5466 & 57 \\
\hline Total & 9513 & 100 \\
\hline
\end{tabular}

In the other disability group, there are developmental disabilities and mental illnesses, learning difficulties, various health problems related to body systems, health problems related to otolaryngology, and internal diseases.

At the qualitative stage, semi-structured interviews were conducted with 20 visually impaired students via the call center of the Open Education faculty. Demographic information of students with visual impairment who participated in the qualitative stage is given in Table 2. According to Table 2, 10 of the visually impaired students who 
participated in the interviews were female, ten were male, the age range was 19-44, and 13 of them were high school graduates, and 7 of them were university graduates. In the open education system, 14 are studying as associate degree students, and 6 are undergraduate students.

Table 2

Demographic Information of Qualitative Stage Participants

\begin{tabular}{lll}
\hline Feature & Variable & Number of participant \\
\hline Gender & Female & 10 \\
& Male & 10 \\
\hline \multirow{2}{*}{ Age range } & Min. & 19 \\
& Max. & 44 \\
\hline Graduation & Average & 32 \\
\hline \multirow{2}{*}{ Educational attainment } & University graduate & 7 \\
& High-school graduate & 13 \\
\hline \multirow{2}{*}{ Vehicle constantly used } & Undergraduate student & 6 \\
& Associate degree student & 14 \\
\hline & White stick & 7 \\
& Screen reader & 3 \\
& Magnifying glass & 2 \\
\hline & Additional software & 8 \\
& support & 4 \\
\hline & Yes & 16 \\
\hline
\end{tabular}

\section{Procedure}

During the implementation phase, the "Open Education Students' Barrier-Free OEF Web Page and ANADOLUM E-Campus System User Experience Questionnaire" developed by the researchers, was submitted to the participants in the online environment and filled in by 9513 students with special needs. After the completion of the questionnaire filling phase, semi-structured interviews were conducted with 20 volunteers and accessible individuals with visual impairment among the students with special needs registered in the Open Education system. Although the interviews were planned to be conducted face- 
to-face with the participants in Eskişehir and via video conference with participants from outside the city, all interviews were conducted by phone due to the pandemic. The interviews were recorded over the call system at Anadolu University Open Education Call Center, and voice approval was obtained by explaining the purpose of the study in each interview.

\section{Data Collection Tools}

Both qualitative and quantitative data collection tools were used in the study. As a qualitative data collection tool, the semi-structured interview form was used in the case study to refer to the participants' individual opinions. The interview is defined as a "conversation in which a person confines himself to asking one or more people about experiences, perceptions, views, and behaviors related to social phenomena, and these people limit themselves to providing answers to these questions" (Boeije, 2010). A semistructured interview is a type of interview in which the interviewer starts the interview with some basic questions, and the questions are detailed according to the answers during the interview (Creswell, 2014). In this study, a semi-structured interview technique was preferred in order to examine the experiences of individuals with special needs in-depth. The interview form consists of five open-ended questions developed by the researchers, which is examining the experiences, difficulties, and solution suggestions of the students while using the Barrier-Free OEF and ANADOLUM E-Kampus system.

At this stage, the questionnaire technique was used as a quantitative data collection tool to determine the experiences of the participants. A questionnaire referred to the questioning technique used to collect information to be used in solving research problems and developed to obtain information in a planned and standardized form (Creswell, 2014; Mills \& Gay, 2016). In the study, "Open Education Students' BarrierFree OEF Web Page and ANADOLUM E-Campus System User Experience Questionnaire" developed by the researchers were used to determine the user experience, difficulties, and needs of students with special needs regarding the Open Education system and eCampus.

\section{Development of the Questionnaire}

Anderson (1990) deals with the questionnaire development process in four stages, as seen in Figure 1; (1) Identifying the Problem: Determining the goal and question, (2) Writing the item: Creating a draft form, (3) Obtaining Expert Opinion: Creating a Preimplementation form and (4) Pre-implementation: finalize the questionnaire. The purpose of the questionnaire used in this research is to determine the user experiences, difficulties, and needs of students with special needs regarding the Barrier-Free OEF web page and ANADOLUM e-Kampus system. The opinions of 20 field experts, the literature on special education and Open Education disciplines, and the flexibility dimensions of Casey and Wilson (2005) were taken into account while creating the questionnaire items. In this process, the questionnaire items created by considering the 
literature on special education and open education disciplines were presented to the opinions of field experts, and arrangements were made regarding content validity and face validity as a result of their feedback. After the arrangements were completed, the clarity of the items, the operability, and the duration of filling the questionnaire were determined with a pilot application with a group of approximately twice the number of items. Questionnaire items were answered in 3-Likert scale answers with the options "I agree-3", "I am neutral-2", and "I disagree-1". The questionnaire consists of 30 items, which the 11 items in the user experience section of the Barrier-Free OEF web page and 19 items in the e-Campus System user experience section.

\begin{tabular}{|c|c|c|c|}
\hline STAGE 1 & STAGE 2 \\
$\begin{array}{c}\text { Identifying the } \\
\text { problem } \\
\begin{array}{c}\text { Determining } \\
\text { goals and } \\
\text { questions }\end{array}\end{array}$
\end{tabular}

Figure 1. Development Process of Questionnaire (Anderson, 1990)

\section{Analysis of Data}

The qualitative data obtained from the interviews were analyzed with content analysis, and the survey data were analyzed with descriptive statistics. The content analysis consists of the steps of transcription of the audio recording, organizing and preparing the data for analysis, reading all the data, coding the data, creating themes, associating the themes, and interpreting the themes (Creswell, 2014). The descriptive statistics of the questionnaire data were calculated by using the SPSS 21 program.

\section{Validity and Reliability}

Questionnaire items were sent to 20 experts in terms of suitability for evaluation. Expert opinions were determined by an expert evaluation form consisting of open and closedended questions. According to expert feedbacks, Lawshe (1975) content validity studies were conducted. According to Lawshe (1975), the content validity rates (CVR) of all the question items and the content validity indexes (CGI) of the Barrier-free OEF and ANADOLUM E-Campus sections of the questionnaire were calculated. Accordingly, the lowest CVR value of the questionnaire items was calculated as 0.9 , the highest CVR value was calculated as 1, and the CGI for the Barrier-Free OEF and ANADOLUM E-Campus sections was 0.98 . After the questionnaire was finalized, the pre-application was carried out with 100 people, and the average response time, the clarity, and operability of the 
items were examined, and the expressions of some items were arranged in terms of clarity.

In the qualitative research phase, internal-external validity in quantitative research, credibility and transferability in qualitative research, internal-external reliability in quantitative research, and consistency and confirmability in qualitative research (Erlandson et al., 1993; Guba and Lincoln, 1989) appear. Expert opinion was taken in the development of the interview form, the breakdown and analysis of the data, and the presentation of the findings in the credibility and consistency stages. In order to ensure transferability, the entire qualitative research process was described in a rich and detailed way, and enough participants $(n=20)$ were reached with purposive sampling. Finally, the audio recordings were listened to by an independent expert and compared with the transcripts to ensure confirmability. Then, a coding reliability study was conducted with an independent expert. Miles, Huberman, and Saldana (2014) stated that the consistency coefficient between coding should be at least $70 \%$ before consensus. Coding reliability was calculated as $87 \%$ before consensus, then researchers and independent experts came together and agreed on the codes with different opinions, and the coefficient after consensus was calculated as $100 \%$.

\section{RESULTS}

In this title, firstly, the quantitative findings obtained from the questionnaire and then the qualitative findings obtained from the semi-structured interviews are included. Quantitative findings, on the other hand, are discussed under two titles. Firstly, the user experiences of the Barrier-Free OEF web page, which is the first part of the questionnaire, and the user experiences of the e-Campus system, which is the second part of the questionnaire, are given in the second section.

\section{User Experiences of Students with Special Needs on the Barrier-Free OEF Web Page}

The answers given to the first part of the 11-item questionnaire, in which the students' opinions with special needs regarding the use of the Barrier-Free OEF web page are determined, are given in Table 3. The questionnaire results for each disability group in Table 3 are summarized separately in the following titles.

\section{Findings Obtained from Students with Visual Impairment}

According to the descriptive statistics given in Table 3, more than half of the students with visual impairments stated that all programs in the Open Education System (OES) were accessible on the Barrier-Free OEF web page (62\%), announcements were made on time (61\%), and guides and instructions were accessible on the web page $(60 \%)$, they could access other services using the web page (60\%), they could easily find the content they were looking for (59\%), and they could register on the web page without needing the help of anyone else. In addition, although with a low rate among the 
negative opinions, the most frequently mentioned subjects were problems with contact with student affairs and the call center (21\%). The highest frequencies are found in the OEF enrollment conditions that cover all disability groups (39\%) and that the regulations for students with disabilities are sufficient (37\%) among the subjects on which students with visual impairments are undecided.

\section{Findings Obtained from Students with Hearing Impairment}

As seen in Table 3, more than half of the students with hearing impairment can access other services (57\%) by using the Barrier-Free OEF web page, and they stated that they could communicate with the Open Education System student affairs when needed (56\%), the announcements are made on the web page (56\%), they could easily access guidelines and instructions (55\%). Despite the positive opinion of the majority, the difficulties stated among students with hearing impairment focus on reaching the call center (30\%), reaching the OES support unit (22\%), and communicating with student affairs $(22 \%)$. It is seen that negative opinions about communication-related items are higher in this disability group, which has problems in language and communication. 


\section{Table 3}

Percentage of Responses of the Participants to the Questionnaires Regarding the Barrier-Free OEF Web Page

\begin{tabular}{|c|c|c|c|c|c|c|c|c|c|c|c|c|c|c|c|}
\hline \multirow{2}{*}{ Ouestionnaire Items } & \multicolumn{5}{|c|}{ Agree (\%) } & \multicolumn{5}{|c|}{ Neutral (\%) } & \multicolumn{5}{|c|}{ Disagree (\%) } \\
\hline & V & $\mathrm{H}$ & $\mathrm{P}$ & $\mathrm{C}$ & 0 & V & $\mathrm{H}$ & $\mathrm{P}$ & $\mathrm{C}$ & 0 & V & $\mathrm{H}$ & $P$ & $\mathrm{C}$ & 0 \\
\hline $\begin{array}{l}\text { 1. I think that OEF registration conditions cover all } \\
\text { disability groups. }\end{array}$ & $\% 43$ & $\% 49$ & $\% 50$ & $\% 46$ & $\% 35$ & $\% 39$ & $\% 32$ & $\% 32$ & \%38 & $\% 42$ & $\% 18$ & \%19 & \%18 & $\% 16$ & $\% 23$ \\
\hline $\begin{array}{l}\text { 2. During the registration period, I can contact the Open } \\
\text { Education System student affairs whenever I need it. }\end{array}$ & $\% 53$ & $\% 56$ & $\% 60$ & $\% 57$ & $\% 49$ & $\% 26$ & $\% 22$ & $\% 21$ & $\% 23$ & $\% 30$ & $\% 21$ & $\% 22$ & $\% 19$ & $\% 20$ & $\% 21$ \\
\hline $\begin{array}{l}\text { 3. I can reach the call center whenever I need it. } \\
\text { 4. When choosing a program, I can easily access }\end{array}$ & $\% 51$ & $\% 46$ & $\% 52$ & $\% 56$ & $\% 48$ & $\% 28$ & $\% 24$ & $\% 24$ & $\% 22$ & $\% 30$ & $\% 21$ & $\% 30$ & $\% 24$ & $\% 22$ & $\% 22$ \\
\hline $\begin{array}{l}\text { information about all programs on the Barrier-Free } \\
\text { OEF web page. }\end{array}$ & $\% 62$ & $\% 53$ & $\% 58$ & $\% 61$ & $\% 53$ & $\% 27$ & $\% 26$ & $\% 24$ & $\% 26$ & $\% 33$ & $\% 11$ & $\% 21$ & $\% 18$ & $\% 13$ & $\% 14$ \\
\hline $\begin{array}{l}\text { 5. When I need help with the Barrier-Free OEF system, I } \\
\text { can reach the OES support unit. }\end{array}$ & $\% 52$ & $\% 49$ & $\% 52$ & $\% 56$ & $\% 48$ & $\% 31$ & $\% 29$ & $\% 29$ & $\% 30$ & $\% 34$ & $\% 17$ & $\% 22$ & $\% 19$ & $\% 14$ & $\% 18$ \\
\hline $\begin{array}{l}\text { 6. I think that the announcements on the Barrier-Free } \\
\text { OEF site were made on time. }\end{array}$ & $\% 61$ & $\% 56$ & $\% 64$ & $\% 60$ & $\% 54$ & $\% 27$ & $\% 29$ & $\% 26$ & $\% 28$ & $\% 33$ & $\% 11$ & $\% 15$ & $\% 10$ & $\% 12$ & $\% 13$ \\
\hline $\begin{array}{l}\text { 7. I can easily access the guides, guidelines, etc., on the } \\
\text { Barrier-Free OEF web page. }\end{array}$ & $\% 60$ & $\% 55$ & $\% 62$ & $\% 61$ & $\% 54$ & $\% 27$ & $\% 28$ & $\% 26$ & $\% 26$ & $\% 33$ & $\% 12$ & $\% 17$ & $\% 12$ & $\% 13$ & $\% 13$ \\
\hline $\begin{array}{l}\text { 8. I think that I can enroll in a program of my choice in } \\
\text { the Open Education system, without needing the help } \\
\text { of anyone else, at the address of } \\
\text { engelsizaof.anadolu.edu.tr. }\end{array}$ & $\% 58$ & $\% 52$ & $\% 63$ & $\% 62$ & $\% 55$ & $\% 32$ & $\% 31$ & $\% 25$ & $\% 29$ & $\% 34$ & $\% 10$ & $\% 17$ & $\% 12$ & $\% 9$ & $\% 11$ \\
\hline $\begin{array}{l}\text { 9. I can easily find the content I am looking for on the } \\
\text { Barrier-Free OEF web page. }\end{array}$ & $\% 59$ & $\% 53$ & $\% 60$ & $\% 60$ & $\% 54$ & \%28 & \%29 & $\% 26$ & $\% 28$ & $\% 35$ & $\% 13$ & \%18 & $\% 14$ & $\% 12$ & $\% 13$ \\
\hline $\begin{array}{l}\text { 10. I think that the special arrangements made for } \\
\text { students with visual/hearing/physical disabilities on } \\
\text { the Barrier-Free OEF website are sufficient. }\end{array}$ & $\% 51$ & $\% 46$ & $\% 55$ & $\% 49$ & $\% 47$ & \%37 & $\% 33$ & $\% 31$ & $\% 39$ & $\% 41$ & $\% 12$ & $\% 19$ & $\% 14$ & $\% 12$ & $\% 12$ \\
\hline $\begin{array}{l}\text { 11. I can easily log in to other services (AKADEMA, e- } \\
\text { Campus, student automation, OES support, etc.) using } \\
\text { the Barrier-Free OEF web page. }\end{array}$ & $\% 60$ & $\% 57$ & $\% 63$ & $\% 64$ & $\% 55$ & $\% 30$ & $\% 29$ & $\% 23$ & $\% 26$ & $\% 34$ & $\% 10$ & $\% 14$ & \%14 & $\% 10$ & $\% 11$ \\
\hline
\end{tabular}

Note: $\mathrm{V}=$ Student with visual impairment, $\mathrm{H}=$ Student with hearing impairment, $\mathrm{P}=\mathrm{Student}$ with physical disability, $\mathrm{C}=\mathrm{Student}$ with chronic disease,

$\mathrm{O}=$ Other disabilities. 


\section{Findings Obtained from Students with Physical Disability}

As can be seen in Table 3, the positive opinions regarding the Barrier-Free OEF web page user experience in the group of students with physical disabilities have been reported respectively as; timely announcements (64\%), registration of a program on the web page without needing the help of others (63\%), and easy access to other services using the web page (63\%), easy access to the guides and instructions on the web page $(62 \%)$, easy access to the content on the web page (60\%), communication with student affairs (60\%) and access to all programs on the web page (58\%). On the other hand, it is seen that students with physical disabilities have difficulties in reaching the call center (24\%), communicating with student affairs (19\%), and accessing the OES support unit (19\%).

\section{Findings Obtained from Students with Chronic Disease}

According to Table 3, the subjects that the students with chronic diseases are most satisfied within the user experience of the Barrier-Free OEF web page are being able to access other services using the web page (64\%), registering for a program through the web page without needing the help of someone else (62\%), accessing all programs from the web page, easy access to guides and instructions (61\%), easily finding the desired content on the web page $(60 \%)$, making the announcements on the web page on time (60\%). The subjects, which students with chronic diseases give negative opinions, concentrate on reaching the call center $(22 \%)$ and communicating with student affairs (20\%), like students with visual, hearing, and physical disabilities.

\section{Findings Obtained from Students with Other Disabilities}

Other disabilities include mental retardation and mental illnesses, learning difficulties, pervasive developmental disorders, ear, nose, and throat-related health problems, various health problems related to body systems such as the digestive system, nervous system, endocrine system, hematopoietic system, and disabilities based on internal diseases. Among these disabilities, intellectual disability, mental illness, and pervasive developmental disorders are so few that they can be ignored among all disability groups. Therefore, in this study, it can be said that the majority of the participants who marked the "other disabilities" option had health-related disabilities.

As can be seen in Table 3, more than half of the other disability group, which makes up $81 \%$ of the special needs students enrolled in Open Education, can enroll in any program they want from the website of hindsizaof.anadolu.edu.tr without needing help (55\%), and they stated that they could access AKADEMA, e-Kampüs through this website, they can easily access other services such as automation (55\%), they can find the guides and instructions they are looking for easily (54\%), they can find the content they are looking for easily (54\%), and timely announcements are made on the website (54\%). Among the opinions that the students in the other disability group did not agree with was that the registration conditions of the OEF cover all disability groups (23\%), it is difficult to reach 
the call center when needed (22\%), it is difficult to communicate with student affairs (21\%) and to reach the OES support unit (18\%).

\section{User Experiences of Students with Special Needs on ANADOLUM E-Campus Findings Obtained from Students with Visual Impairment}

According to Table 4, 60\% and more of students with visual impairments can easily download and save the learning materials in the e-Campus system (65\%), enter the eCampus without the need for anyone else (64\%), access the courses without the need for anyone else (63\%), and they granted the usefulness of the announcements made on the e-Campus (61\%) and the ease of use of the e-Campus system web page $(60 \%)$. Communicating with the instructors (18\%), getting support from the OES support unit $(17 \%)$, the duration of the courses, and the time given for the trial exam are sufficient (14\%) are among the opinions that visually impaired individuals most frequently disagree with.

\section{Findings Obtained from Students with Hearing Impairment}

According to Table 4, 60\% of the students with hearing impairment were able to enter the e-Campus without needing help from someone else, 59\% were able to enter the courses in the e-Campus, $57 \%$ could complete the online exams, 57\% could easily download and save the learning materials in the courses. $27 \%$ of the students with hearing impairment stated that they could not communicate with the lecturers of the course in the e-Campus, $20 \%$ of them stated that they could not easily reach the OES support unit, $19 \%$ of them stated that they did not have sufficient course time, $19 \%$ of them stated that they could not access learning materials in live lessons, 19\% of them stated that the duration of the trial exams was not sufficient.

\section{Findings Obtained from Students with Physical Disability}

As seen in Table 4, 67\% of the students with physical disabilities were able to enter the e-campus without the help of anyone else, 66\% could complete the online exams without the help of someone else, $66 \%$ could easily download and save the course materials, $65 \%$ could attend the classes on e-campus without the help of anyone else, $63 \%$ stated that e-campus announcements were useful, $61 \%$ stated that the web page was easy to use, and $60 \%$ could take the trial exams without the help of someone else. The most frequently mentioned issues among the opinions that students with physical disabilities do not agree with are as follows; Communicating with the lecturers of the course in the e-campus (22\%), receiving support from the OES support unit about the ecampus (19\%), allocating sufficient time for questions and answers in live lessons $(18 \%)$, and the duration of the courses in the e-Campus is sufficient (17\%). 
Table 4

Percentage of Responses of Participants to Questionnaire Items Related to the E-Campus System

\begin{tabular}{|c|c|c|c|c|c|c|c|c|c|c|c|c|c|c|c|}
\hline \multirow{2}{*}{ Ouestionnaire Items } & \multicolumn{5}{|c|}{ Agree (\%) } & \multicolumn{5}{|c|}{ Neutral (\%) } & \multicolumn{5}{|c|}{ Disagree (\%) } \\
\hline & V & $\mathrm{H}$ & $P$ & $\mathrm{C}$ & 0 & $\mathrm{~V}$ & $\mathrm{H}$ & $P$ & $\mathrm{C}$ & 0 & $\mathrm{~V}$ & $\mathrm{H}$ & $P$ & $\mathrm{C}$ & 0 \\
\hline $\begin{array}{l}\text { 1. I can easily communicate with the instructors who } \\
\text { conduct the courses on the e-Campus. }\end{array}$ & $\% 41$ & $\% 42$ & $\% 46$ & $\% 35$ & $\% 42$ & $\% 41$ & $\% 31$ & $\% 31$ & $\% 41$ & $\% 40$ & $\% 18$ & $\% 27$ & $\% 22$ & $\% 24$ & $\% 18$ \\
\hline $\begin{array}{l}\text { 2. When I have a problem with the E-Campus system, I } \\
\text { can easily get support from the OES support unit. }\end{array}$ & $\% 47$ & $\% 48$ & $\% 48$ & $\% 47$ & $\% 47$ & $\% 36$ & $\% 32$ & $\% 33$ & $\% 37$ & $\% 34$ & $\% 17$ & $\% 20$ & $\% 19$ & $\% 17$ & $\% 19$ \\
\hline $\begin{array}{l}\text { 3. I think the announcements made on the e-Campus are } \\
\text { useful. }\end{array}$ & $\% 61$ & $\% 55$ & $\% 63$ & $\% 65$ & $\% 57$ & $\% 29$ & $\% 29$ & $\% 25$ & $\% 26$ & $\% 32$ & $\% 10$ & $\% 16$ & $\% 13$ & $\% 9$ & $\% 11$ \\
\hline $\begin{array}{l}\text { 4. I think the duration of the courses on the E-Campus is } \\
\text { sufficient. }\end{array}$ & $\% 52$ & $\% 53$ & $\% 53$ & $\% 53$ & $\% 49$ & $\% 34$ & $\% 28$ & $\% 30$ & $\% 32$ & $\% 38$ & $\% 14$ & $\% 19$ & $\% 17$ & $\% 15$ & $\% 13$ \\
\hline $\begin{array}{l}\text { 5. I think there is enough time for question-answer in } \\
\text { live lessons. }\end{array}$ & $\% 42$ & $\% 46$ & $\% 40$ & $\% 38$ & $\% 42$ & $\% 45$ & $\% 37$ & $\% 41$ & $\% 47$ & $\% 43$ & $\% 13$ & $\% 17$ & $\% 18$ & $\% 15$ & $\% 15$ \\
\hline $\begin{array}{l}\text { 6. I think that the time given for the trial exams in the E- } \\
\text { Campus is sufficient. }\end{array}$ & $\% 47$ & $\% 48$ & $\% 49$ & $\% 53$ & $\% 46$ & $\% 39$ & $\% 33$ & $\% 34$ & $\% 34$ & $\% 40$ & \%14 & \%19 & $\% 17$ & $\% 13$ & $\% 14$ \\
\hline $\begin{array}{l}\text { 7. I think that life lessons are conducted in an interactive } \\
\text { way. }\end{array}$ & $\% 46$ & $\% 48$ & $\% 47$ & $\% 41$ & $\% 44$ & $\% 42$ & $\% 35$ & $\% 39$ & $\% 44$ & $\% 43$ & $\% 12$ & $\% 17$ & $\% 14$ & $\% 15$ & $\% 13$ \\
\hline $\begin{array}{l}\text { 8. I can easily access learning materials such as libraries, } \\
\text { web pages, pdfs, ppts, videos, animations, etc., used in } \\
\text { live lessons. }\end{array}$ & $\% 50$ & $\% 48$ & $\% 54$ & $\% 51$ & $\% 48$ & $\% 37$ & $\% 33$ & $\% 30$ & $\% 37$ & $\% 39$ & \%13 & $\% 19$ & $\% 16$ & $\% 12$ & $\% 13$ \\
\hline $\begin{array}{l}\text { 9. I think that the learning materials used in live lessons } \\
\text { are specially prepared for students with visual } \\
\text { impairment. }\end{array}$ & $\% 45$ & $\% 44$ & $\% 50$ & $\% 45$ & $\% 44$ & $\% 43$ & $\% 41$ & $\% 34$ & $\% 43$ & $\% 44$ & $\% 12$ & $\% 15$ & $\% 16$ & $\% 12$ & $\% 12$ \\
\hline $\begin{array}{l}\text { 10. I think that visual and auditory supports such as } \\
\text { videos, photographs, animations are used in live } \\
\text { lessons. }\end{array}$ & $\% 46$ & $\% 47$ & $\% 48$ & $\% 45$ & $\% 46$ & $\% 42$ & $\% 36$ & \%38 & $\% 44$ & $\% 43$ & $\% 12$ & $\% 17$ & $\% 14$ & $\% 11$ & $\% 11$ \\
\hline $\begin{array}{l}\text { 11. I think that the homework submission deadlines } \\
\text { given in the courses in the E-Campus are appropriate. }\end{array}$ & $\% 43$ & $\% 43$ & $\% 43$ & $\% 42$ & $\% 43$ & $\% 47$ & $\% 39$ & $\% 40$ & $\% 45$ & $\% 45$ & $\% 10$ & \%18 & $\% 17$ & $\% 13$ & $\% 12$ \\
\hline
\end{tabular}

Note: $\mathrm{V}=$ Student with visual impairment, $\mathrm{H}=$ Student with hearing impairment, $\mathrm{P}=$ Student with physical disability, $\mathrm{C}=\mathrm{Student}$ with chronic disease, $0=$ Other disabilities 


\section{Table 4 (continued)}

\begin{tabular}{|c|c|c|c|c|c|c|c|c|c|c|c|c|c|c|c|}
\hline \multirow{2}{*}{ Ouestionnaire Items } & \multicolumn{5}{|c|}{ Agree (\%) } & \multicolumn{5}{|c|}{ Neutral (\%) } & \multicolumn{5}{|c|}{ Disagree (\%) } \\
\hline & V & $\mathrm{H}$ & $\mathrm{P}$ & $\mathrm{C}$ & 0 & $\mathrm{~V}$ & $\mathrm{H}$ & $\mathrm{P}$ & $\mathrm{C}$ & 0 & V & $\mathrm{H}$ & $\mathrm{P}$ & $\mathrm{C}$ & 0 \\
\hline $\begin{array}{l}\text { 12. I think that the instructions presented in the e- } \\
\text { Campus courses are sufficient to carry out the } \\
\text { assignments. }\end{array}$ & $\% 46$ & $\% 43$ & $\% 46$ & $\% 45$ & $\% 44$ & $\% 44$ & $\% 41$ & $\% 38$ & $\% 42$ & $\% 44$ & $\% 10$ & $\% 16$ & $\% 16$ & $\% 13$ & $\% 12$ \\
\hline $\begin{array}{l}\text { 13. I think that the way the exams held in the e-Campus } \\
\text { are administered is suitable for students with visual } \\
\text { impairment. }\end{array}$ & $\% 48$ & $\% 47$ & $\% 50$ & $\% 47$ & $\% 45$ & $\% 41$ & $\% 38$ & $\% 34$ & $\% 41$ & $\% 44$ & $\% 11$ & $\% 15$ & $\% 16$ & $\% 12$ & $\% 11$ \\
\hline $\begin{array}{l}\text { 14. I can complete the practice exams on the e-Campus } \\
\text { without needing the help of someone else. }\end{array}$ & $\% 55$ & $\% 52$ & $\% 60$ & $\% 64$ & $\% 53$ & $\% 33$ & $\% 30$ & $\% 26$ & $\% 27$ & $\% 37$ & $\% 12$ & $\% 18$ & $\% 14$ & $\% 9$ & $\% 10$ \\
\hline $\begin{array}{l}\text { 15. By using esinav.anadolu.edu.tr, I can complete the } \\
\text { online exams without the help of anyone else. }\end{array}$ & $\% 60$ & $\% 57$ & $\% 66$ & $\% 68$ & $\% 57$ & $\% 30$ & $\% 29$ & $\% 22$ & $\% 22$ & $\% 33$ & $\% 10$ & $\% 14$ & $\% 12$ & $\% 10$ & $\% 10$ \\
\hline $\begin{array}{l}\text { 16. I can enter the e-Campus without the help of anyone } \\
\text { else. }\end{array}$ & $\% 64$ & $\% 60$ & $\% 67$ & $\% 73$ & $\% 59$ & $\% 28$ & $\% 26$ & $\% 20$ & $\% 20$ & $\% 32$ & $\% 8$ & $\% 14$ & $\% 13$ & $\% 7$ & $\% 9$ \\
\hline $\begin{array}{l}\text { 17. I can enter the courses held on the e-Campus without } \\
\text { needing the help of someone else. }\end{array}$ & $\% 63$ & $\% 59$ & $\% 65$ & $\% 73$ & $\% 58$ & $\% 28$ & $\% 26$ & $\% 23$ & $\% 19$ & $\% 32$ & $\% 9$ & $\% 15$ & $\% 12$ & $\% 8$ & $\% 10$ \\
\hline 18. I think the e-Campus system web page is easy to use. & $\% 60$ & $\% 55$ & $\% 61$ & $\% 63$ & $\% 57$ & $\% 30$ & $\% 27$ & $\% 26$ & $\% 24$ & $\% 33$ & $\% 10$ & $\% 18$ & $\% 13$ & $\% 13$ & $\% 10$ \\
\hline $\begin{array}{l}\text { 19. I can easily download and save the learning materials } \\
\text { (pdf, ppt, etc.) presented in the lessons. }\end{array}$ & $\% 65$ & $\% 57$ & $\% 66$ & $\% 64$ & $\% 58$ & $\% 26$ & $\% 29$ & $\% 23$ & $\% 24$ & $\% 33$ & $\% 9$ & $\% 14$ & $\% 11$ & $\% 12$ & $\% 9$ \\
\hline
\end{tabular}

Note: $\mathrm{V}=$ Student with visual impairment, $\mathrm{H}=$ Student with hearing impairment, $\mathrm{P}=\mathrm{Student}$ with physical disability, $\mathrm{C}=\mathrm{Student}$ with chronic disease,

$0=$ Other disabilities 


\section{Findings Obtained from Students with Chronic Diseases}

According to Table 4, 73\% of the students with chronic diseases were able to enter the eCampus and courses without needing the help of someone else, $68 \%$ of them were able to complete the online exams, $65 \%$ of them said that the announcements on the ecampus were useful, $64 \%$ of them stated that they were able to learn from the courses, $64 \%$ of them stated that they could easily download and save their materials, $64 \%$ of them stated that they could take practice exams alone, and $63 \%$ of them stated that the e-Campus system web page was easy to use. $24 \%$ of the students with chronic diseases stated that they could not communicate with the lecturers of the course in the e-Campus, and $17 \%$ of them stated that they could not get support regarding the e-campus in the OES support unit.

\section{Findings Obtained from Students with Other Disabilities}

According to Table 4, the students in the other disability group stated that "I agree" about the following subjects as follows; $59 \%$ of them entering the e-Campus without the need for anyone else, 58\% of them easily downloading and saving the learning materials in the e-Campus system, $58 \%$ of them entering the e-campus without needing anyone else, $57 \%$ of them, the ease of use of the e-Campus system web page, $57 \%$ of them completing the online exams without needing the help of anyone else, and $57 \%$ of them making useful announcements on the e-campus. Among the opinions that the students in the other disability group did not agree with, the most frequently stated issues were communicating with the instructors $(18 \%)$ and receiving support from the OES support unit (19\%).

\section{Most Reported Areas for Improvement in All Disability Groups}

In the previous titles, the findings regarding the Barrier-Free OEF web page and eCampus user experiences of students belonging to all disability groups were shared. Accordingly, the most frequently stated "disagree" answers in all disability groups are summarized in Table 5.

In Table 5, the most frequently expressed items among the negative responses ("disagree") are given by each disability group to both the User experience items of the Barrier-Free OEF Web Page and the user experience items of the E-Campus System. Accordingly, regardless of the type of disability, more than $18 \%$ of all students with special needs stated that they could not easily communicate with student affairs, call centers, and OES support units. When we look at the descriptive statistics, it is seen that the highest percentage is the students with hearing impairment who have negative opinions about reaching the call center in case of need with $30 \%$ and communicating with the instructors teaching the e-Campus course with $27 \%$. 
Table 5

Items with the Most "I Disagree" Responses in the Use of the Barrier-Free OEF Web Page and E-Campus System by Students with Special Needs Registered in Open Education

\begin{tabular}{|c|c|c|c|}
\hline ITEM & GROUP & $\begin{array}{l}\text { Barrier } \\
\text { Free OEF }\end{array}$ & $\begin{array}{c}\text { E- } \\
\text { Campus }\end{array}$ \\
\hline \multirow{3}{*}{$\begin{array}{l}\text {-I can communicate with the Open Education } \\
\text { System student affairs whenever I need it during } \\
\text { the registration process. (Barrier-Free OEF Web } \\
\text { Page) }\end{array}$} & Hearing impairment & $22 \%$ & $27 \%$ \\
\hline & Visual impairment & $21 \%$ & $18 \%$ \\
\hline & Other disabilities & $21 \%$ & $18 \%$ \\
\hline \multirow{2}{*}{$\begin{array}{l}\text {-I can easily communicate with the instructors } \\
\text { who conduct the courses on the E-Campus. (E- } \\
\text { Campus System) }\end{array}$} & Chronic disease & $20 \%$ & $24 \%$ \\
\hline & Physical disability & $19 \%$ & $22 \%$ \\
\hline \multirow{5}{*}{ I can reach the call center whenever I need it. } & Hearing impairment & $30 \%$ & - \\
\hline & Physical disability & $24 \%$ & - \\
\hline & Chronic disease & $22 \%$ & - \\
\hline & Other disabilities & $22 \%$ & - \\
\hline & Visual impairment & $21 \%$ & - \\
\hline \multirow{5}{*}{$\begin{array}{l}\text { - When I need help with the barrier-free OEF } \\
\text { system, I can reach the OES support unit. } \\
\text { - When I have a problem in the E-Campus } \\
\text { system, I can easily get support from the OES } \\
\text { support unit. }\end{array}$} & Hearing impairment & $22 \%$ & $20 \%$ \\
\hline & Physical disability & $19 \%$ & $19 \%$ \\
\hline & Other disabilities & $18 \%$ & $19 \%$ \\
\hline & Visual impairment & $17 \%$ & $17 \%$ \\
\hline & Chronic disease & $14 \%$ & $17 \%$ \\
\hline \multirow{3}{*}{$\begin{array}{l}\text { I think that OEF registration conditions cover all } \\
\text { disability groups. }\end{array}$} & Hearing impairment & $19 \%$ & - \\
\hline & Visual impairment & $18 \%$ & - \\
\hline & Physical disability & $18 \%$ & - \\
\hline \multirow{3}{*}{$\begin{array}{l}\text { When choosing a program, I can easily access } \\
\text { information about all programs on the Barrier- } \\
\text { Free OEF web page. }\end{array}$} & Other disabilities & $23 \%$ & - \\
\hline & Hearing impairment & $21 \%$ & - \\
\hline & Ortopedik yetersizlik & $18 \%$ & - \\
\hline \multirow{5}{*}{$\begin{array}{l}\text { I think that the time given for practice exams in } \\
\text { E-Campus is sufficient. }\end{array}$} & Hearing impairment & - & $19 \%$ \\
\hline & Physical disability & - & $17 \%$ \\
\hline & Other disabilities & - & $14 \%$ \\
\hline & Visual impairment & - & $14 \%$ \\
\hline & Chronic disease & - & $13 \%$ \\
\hline
\end{tabular}


In addition to these, it is seen that most of the students who stated that they did not agree with the opinion that OEF registration conditions cover all disability groups had heard, visual, and physical disabilities. Most of the students who do not agree with the opinion that they can easily access all programs from the barrier-free OEF web page are in the group of hearing impairment, physical inadequacy, and other disabilities. In addition to these, another remarkable issue is that trial exams in the e-Campus system do not include sufficient time. Especially students with hearing impairment (19\%) reported negative opinions on this subject.

In summary, it has been concluded that students in all disability groups have difficulties in communication support in the user experience of the Barrier-Free OEF web page and e-Campus system. In addition, among the most frequently reported topics were that the enrollment conditions for the program were not sufficient, it was not easy to access all programs from the web page, and sufficient time was not given for practice exams.

\section{Findings Obtained from the Interviews}

With 9513 students with special needs who participated in the research, user experiences of the Barrier-Free OEF web page and e-Campus system were determined through a questionnaire, then 20 students with visual impairment who were voluntarily selected among the students with $80 \%$ or more visual impairment formed by criterion sampling from the research population were reached, and semi-structured interviews were conducted. As a result of the content analysis of the interviews, the qualitative findings were divided into sub-themes and codes under four main themes. Accordingly, the findings obtained from the interviews are summarized in Table 6.

As can be seen in Table 6, the themes that emerged as a result of semi-structured interviews with students with visual impairment (1) Opinions about the Open Education System and Barrier-Free OEF, (2) opinions about the e-campus, (3) opinions about the call center and OES support system, and (4) needed support and advice. While it is stated that the web page is easy to use on the Open Education System and Barrier-Free $\mathrm{OEF}$, one of the frequently expressed opinions is the difficulties experienced in running the additional software of the system. On this subject, Ms. Berna said, "Yes, the voice-over program I mentioned can sometimes not be able to fully read every part that is not very accessible on the website", Mr. Doruk said, "How can I say that the Jaws program can't read the writings on the signboard like this? Normally, it cannot read the colored texts or the texts on the book, so ir only reads the contents of the book". In addition, students with visual impairment reported some difficulties in using the login screen of the mobile application regarding the interface. Ms. Berna stated that "When logging in to Anadolu University while logging in on the iOS application, it cannot read the login part, the user name, e-mail and password part...", Ms. Pelin stated that "I have difficulties in logging in from the mobile application, it would be very good if the login screen is corrected". In addition, some participants stated that they had difficulty logging into the mobile application and opening some audiobooks, and they could not access the videos of the recorded lessons. 
Table 6

Findings Obtained from the Interviews

Themes and Sub-Themes

1) Opinions on Open Education System and Barrier-Free OEF

Easy Use of the Barrier-Free OEF Web Page

Difficulties in Using the Open Education System Application

Difficulties running additional software

Difficulties using mobile app login screen

2) Opinions on E-Campus

Positive Opinions

Presentation of useful content

Easy use of the system

Negative Opinions

Lack of audiobooks for some courses

Difficulties accessing recorded videos of lectures

3) Opinions on the Call Center and OES Support System

Positive Opinions

Providing fast return

Showing interest

Negative Opinions

Difficulties accessing call center or OES support

4) Needed Support and Suggestions

Requested Supports

Production of audiobooks with human voice

Making notifications by phone to the visually impaired

Voice guidance on the home page

Simplifying screen reader programs

Increasing the audio narration of the lessons

Readability of PDFs by all audio programs

Easy access to live lessons 
Simplification of the barrier-free Web page: Accessing to all applications from one place

Enlargement of texts during the exam

Extra time in exams

Suggestions

Expanding course content

Adding summary information about the content of the courses on the course selection page

Positive thoughts on the use of the e-Campus system are dominated by the opinion that the system is easy to use and useful content is presented. In the negative opinions, four of the participants stated that some subjects did not have audiobooks and they needed them, and two of them stated that they had difficulty accessing the recorded lecture videos.

Most of the participants gave a positive opinion on the call center and OES support system in the form of a fast return and showing interest and concern. On the other hand, some of the students with visual impairment reported that they had difficulty in accessing the call center and OES support, which is one of the issues frequently mentioned in the quantitative findings. Regarding the exams that were informed via SMS, Ms. Gülru stated that "...only a message has been received about the last midterm exams, but for example, information such as the start of your exam and the end of it is this day might be better."

Visually impaired students stated that they needed various support for some difficulties they experienced using the Barrier-Free OEF web page and e-Campus. These supports can be summarized as follows:

- Preparation of audiobooks with human voice instead of mechanical voice over

- Providing access to visually impaired students by phone for the messages and announcements coming from the system.

- Using voice prompts for typing username, e-mail, and password on the login page

- Clarifying the directions of screen reader programs with the help of cursors, simplifying their use,

- Increasing the audio narration materials (audio summary, audiobook) rather than the written text and content in the lessons,

- Making arrangements for additional software so that additional software used by students with special needs can read all PDFs,

- Simplifying the user interface for easier access to live lessons, 
- Simplifying the web page and accessing all applications (Barrier-Free OEF, Anadolu University, e-Kampus, etc.) from a single home page,

- Making the necessary arrangements to enlarge the texts in online exams,

- Giving additional time for online exams.

In addition to these supports, the participants stated that the course contents for students with special needs could be expanded in the Open Education System and that a presentation could be made by adding summary information about the content of the courses on the course selection page.

\section{DISCUSSION, CONCLUSION AND RECOMMENDATIONS}

According to the findings obtained through the questionnaire in the quantitative dimension of the research, the subjects that individuals with special needs recommend making arrangements regardless of the type of disability are, frequently, communication with student affairs, call center and OES support units, reaching to the call center in case of need, communication with the instructors who conduct the e-Campus course (See Table 5). In open and distance learning processes, it can be said that learners should be in constant communication with the learners throughout the process in order to prevent the social isolation they have experienced due to their physical distance (Kılınç, 2021). In this way, it is also possible to prevent learners from isolating themselves from their learning processes. In addition to this situation, it was seen in the interview findings that the issues of access to the call center and OES support should be addressed. At this point, it has been concluded that communication ways of students with special needs should be considered in the use of both the Barrier-Free OEF and the e-Campus System. Similar to the results reached in the context of the services provided for learners with special needs, Emiroğlu (2015) states that within the scope of the institutions to which the individuals with special needs are affiliated, they have a great need for communication issues such as being able to express themselves and quickly convey the problems they experience. In another study, Hamilton and Keten (2011) stated that accessing and benefiting from information sources is one of the most needed issues for individuals with special needs. In line with the findings of the research, it can be suggested to strengthen the communication channels, establish consultancy teams, including a special education specialist, for the call center and the OES support unit, and develop alternative systems that will provide instant communication.

It has been concluded that communication ways should be considered in the use of the MPUS System. Similar to the results reached in the context of the services provided for learners with special needs, Emiroğlu (2015) states that within the scope of the institutions to which the individuals with special needs are affiliated, they have a great need for communication issues such as being able to express themselves and quickly convey the problems they experience. In another study, Hamilton and Keten (2011) 
stated that accessing and benefiting from information sources is one of the most needed issues for individuals with special needs. In line with the findings of the research, it can be suggested to strengthen the communication channels, establish consultancy teams, including a special education specialist, for the call center and the OES support unit, and develop alternative systems that will provide instant communication.

On the other hand, as can be seen in Table 5, hearing impairment is the group with the highest frequency, which states that arrangements should be made at some points in easy communication with student affairs, OES support, call center, or instructors teaching on e-Campus. It is thought that this situation may be due to the difficulties they experience in language and communication due to the nature of their hearing impairment. Therefore, special arrangements for hearing impairment are needed in the development of communication channels. Emiroğlu (2015) also underlined that the written communication necessary for learners with hearing impairment should be found on institutions' web pages. However, in another study conducted by Şahin-İzmirli, Dönmez, and Kabakçı-Yurdakul (2011), university Web pages were examined, and as a result, it was stated that the features that facilitated individuals with special needs to navigate the Web pages were limited. Written live support application especially for students with hearing impairment in order to prevent hearing and speaking difficulties, easy-to-access text messaging section on the barrier-free OEF homepage, providing written access to the call center, automatic message patterns, and creation of written notification options specific to the registration week and exam period can be recommended.

Another group with high participants (See Table 5) who reported negative responses in the field of communication is students with visual impairment. It is thought that this situation is caused by the difficulty in using the interface and the inaccessibility of communication channels due to visual impairment. In a study examining the problems experienced by individuals with visual impairments on Web sites, it was stated that screen reader and font enlarger programs should be used in order to eliminate these problems (Hamilton \& Keten, 2011). Access to the call center, OES support, and student affairs department with voice prompts on the Barrier-Free OEF web page for this group, which has difficulties in seeing and therefore reading, giving the relevant contact numbers aloud in case of accessing this section, using screen readers and writing the communication channels in large font and in color will avoid difficulties.

Another important issue that needs to be regulated is access to information about the programs on the Barrier-Free OEF web page. Individuals with special needs stated that they would like to access information about all programs on the web page when choosing a program. In addition, the findings obtained in the qualitative phase of the research are that, in parallel with the quantitative findings, summary information about the contents of the courses should be included on the course selection page. In line with the principle of openness in education, it is essential that all programs are accessible to all students (Ekren \& Kumtepe, 2018). At this point, it is recommended to add a tab that 
provides access to all programs from a single link on the main page of Barrier-Free OEF, and to include introductory summary information about each program in the tab.

Another common issue in the quantitative and qualitative stages is the duration of the exams. Findings from the survey show that additional time should be given to practice exams (See Table 5). As a matter of fact, in the interviews, the participants brought up the issue of giving additional time to the exams. Since open education online exams are collective exams structured throughout the country and held simultaneously, it can be recommended to reduce the number of questions related to the difficulty of individuals with special needs not being able to complete the exams instead of changing the duration. In the current online exam system, 40 minutes is given for 30 questions. In the face-to-face exams held before the pandemic, there were 20 questions for each lesson in the exam booklet, and 30 minutes were given. Therefore, with regard to the additional time support request specified in the study, this difficulty can be improved by arranging 20 questions for 40 minutes in online exams, in other words, by reducing the number of questions. Similar to this result obtained within the scope of the study, in studies conducted on the problems experienced by students with special needs in exams, it was stated that these students needed additional time in exams (Furat, 2012; Şenel, 2015). Therefore, it can be said that individuals with special needs should also be helped in the examination process.

Situations mentioned in the interviews with students with visual impairment, as can be seen in the findings title, consists of access to the user interface of the Accessible OEF web page and e-Campus system, the support of these pages for additional software specific to the visually impaired, the completion of audiobooks, the arrangement of the introduction to the Open Education system mobile application, the course, and adapting the materials and exam practices according to all disability groups (See Table 6). In the study conducted by Rosa and Valentim (2020), the needs of individuals with visual impairments for the development of different typological elements such as screen size, button shapes, and color intensity were stated. The "Barrier-Free Menu" developed for individuals with visual impairment in the Anadolu University e-Campus system adapts the aforementioned items such as size, color, and shape specifically for the user. At this point, the fact that the emphasis on these elements in the research findings is limited to enlarging the texts in online exams can be explained by the "Barrier-Free Menu", which is used effectively. On the other hand, in line with the support requests of students with visual impairment and the literature (Cho, 2021; Rosa \& Valentim, 2020; Yusril, 2020), suggestions to overcome these situations can be listed as creating audiobooks for all courses and recording with human voice instead of machine voice if possible, designing a user interface special for students with visual impairment in both the Barrier-Free OEF and e-Campus systems, simplifying the interface, adding voice prompts for the entrance and accessing the relevant section, enlarging the texts in online exam applications and giving additional time, and finally, making the system compatible with additional software such as Voice Over and Jaws used by students with visual impairment. 
Parallel to all these results, studies conducted in the relevant literature (Bühler \& Fisseler, 2007; Petrie et al., 2006; Santos, Couchet, \& Boticario, 2009; Okur \& Demir, 2019; Rosa \& Valentim, 2020; Schrepp et al., 2017; Yusril, 2020) emphasized that it is an important requirement to include user experiences in systems such as Web sites used by individuals with special needs and to make arrangements accordingly. At this point, it can be suggested that designs should be made in line with universal design principles and user-centered design principles during the arrangements to be made. Within the scope of this study, which was carried out specifically for Anadolu University, the difficulties experienced in the Barrier-Free OEF and e-Campus system were revealed in the light of the findings obtained as a result of including the experiences of students with special needs while using the learning systems. In this direction, necessary arrangements will be made, and systems will be improved. In parallel with this situation, Rosa and Valentim (2020) emphasized that user experiences are an important factor in increasing the quality of learning systems within the scope of their study. However, considering that the usability of Web sites is a very important point for individuals with special needs (King et al., 2005), it can be stated that this study has led to more efficient use of learning systems used by Anadolu University, which has the highest number of students with special needs at the national level. The more usable learning systems will make it possible for learners with special needs to have richer learning experiences. In addition, the increase in the usability of the learning systems used by learners with special needs will bring together the elements of effectiveness, efficiency, and satisfaction (ISO, 2000). It is thought that the findings obtained based on this study conducted in Anadolu University Open Education System, which is a pioneer in terms of the number of students with special needs, will provide very valuable outputs for other higher education institutions that carry out open and distance learning activities.

\section{References}

Anderson, G. (1990). Fundamentals of educational research. Bristol: The Falmer Press.

Baird, D. E., \& Fisher, M. (2005). Neomillennial user experience design strategies: Utilizing social networking media to support "always on" learning styles. Journal of Educational Technology Systems, 34(1), 5-32.

Boeije, H. (2010). Analysis in qualitative research. SAGE Publication.

Bozkurt-Sani, S. (2017). Özel eğitimde dijital destek: Yardımcı teknolojiler [Digital support in special education: Assistive technologies]. Açıöögretim Uygulamaları ve Araştırmaları Dergisi, 3(2), 37-60.

Bühler, C., \& Fisseler, B. (2007). Accessible e-learning and educational technology-extending learning opportunities for people with disabilities. Conference ICL2007, September 26 -28, 2007, Villach, Austria.

Büyüköztürk, Ş. (2005). Anket geliştirme [Survey Development]. Türk Eğitim Bilimleri Dergisi, $3(2), 133-151$. 
Carneiro, L., Rebelo, F., Filgueiras, E., \& Noriega, P. (2015). Usability and user experience of technical aids for people with disabilities? A preliminary study with a wheelchair. Procedia Manufacturing, 3, 6068-6074.

Chmiliar, l. (2010). Multiple-case designs. In A. J. Mills, G. Eurepas \& E. Wiebe (Eds.), Encyclopedia of case study research (pp 582-583). USA: SAGE Publications.

Cho, J. D. (2021). A study of multi-sensory experience and color recognition in visual arts appreciation of people with visual impairment. Electronics, 10(4), 470-507.

Cooper, M., Colwell, C., \& Jelfs, A. (2007). Embedding accessibility and usability: considerations for e-learning research and development projects. ALT-J, 15(3), 231-245.

Creswell, J. W. (2014). Research design: Qualitative, quantitative, and mixed methods approach. (4th Edition). SAGE Publications.

Demetriadis, S., \& Pombortsis, A. (2007). E-lectures for flexible learning: A study on their learning efficiency. Educational Technology \& Society, 10(2), 147-157.

Durmuş, S., \& Çağıltay, K. (2012). Kamu kurumu web siteleri ve kullanılabilirlik [Public agency websites and usability]. M. Z. Sobacı ve M. Yıldız (Ed.) E-devlet kamu yönetimi ve teknoloji ilişsisinde güncel gelişmeler (s. 293-322.).

Edyburn, D. L. (2001). Models, theories, and frameworks: Contributions to understanding special education technology. Special Education Technology Practice, 4(2), 16-24.

Ekren, G., \& Kumtepe, E. G. (2018). Yükseköğrenim düzeyinde uzaktan eğitimde "açıklık" kavramına yönelik içerik analizi [Content analysis for the concept of "openness" in distance education at higher education level]. Açıöğretim Uygulamaları ve Araştırmaları Dergisi, 4(2), 112-128.

Emiroğlu, B. G. (2015). Üniversitelerin engelli destek ofislerinin web sayfalarının erişilebilirlikleri [Accessibility of the web pages of the disability support offices of the universities]. Journal of Educational Sciences \& Practices, 14(27), 43-55.

Emre, İ. E., Akadal, E., \& Gülseçen, S. (2018). Örgün ve uzaktan eğitim öğrencileri için kullanılabilirlik araştırması: Marmara Üniversitesi web sitesi [Usability research for formal and distance education students: Marmara University website]. Uluslararası Yönetim Bilişim Sistemleri ve Bilgisayar Bilimleri Dergisi, 2(1), 12-22.

Erlandson, D. A., Harris, E. L., Skipper, B. L., \& Allen, S. D. (1993). Doing naturalistic inquiry: A guide to methods. SAGE Publication.

Furat, E. (2012). Görme engelli öğrencilerin üniversite giriş sınavında karşılaștığı sorunlar ve çözüm önerileri [Problems faced by visually impaired students in the university entrance exam and suggestions for solutions]. III. Eğitimde ve Psikolojide Ölçme ve Değerlendirme Kongresi. Abant İzzet Baysal Üniversitesi. Bolu.

Guba, E. G., \& Lincoln, Y. S. (1989). Fourth generation evaluation. SAGE Publication.

Güler, E. (2018). Açık ve uzaktan öğrenme ortamlarında esneklik [Flexibility in open and distance learning environments]. Açıköğretim Uygulamaları ve Araştırmaları Dergisi, 4(3), 75-95.

Hamilton, D., \& Keten, B. (2011). Görme Engelli Kullanıcılar İçin Erişilebilir Kütüphaneler: Kütüphanecilere Yönelik Pratik Öneriler [Accessible Libraries for Visually Impaired Users: Practical Advice for Librarians]. Türk Kütüphaneciliği, 25(4), 509-518.

Hassenzahl, M. (2013). User experience and experience design. The encyclopedia of humancomputer interaction, 2. Retrieved from https://www.researchgate.net/profile/MarcHassenzahl/publication/259823352_User_Experience_and_Experience_Design/links/56a7 352d08ae997e22bbc807/User-Experience-and-Experience-Design.pdf

Henry, S. L., Abou-Zahra, S., \& Brewer, J. (2014, April). The role of accessibility in a universal web. In Proceedings of the 11th Web for all Conference. MIT Open Access Articles. 
Heward, W. L., Alber, S. R., \& Konrad, M. (2006). Exceptional children: An introduction to special education. Pearson Education/Merrill/Prentice Hall.

International Standards Organization (ISO): Standard 924 (2000). Ergonomic Requirements for Office Work with Visual Display Terminals. ISO, Geneva (1992-2000)

Kılınç, H. (2021). Opinions of Field Experts on Practices That Will Increase the Motivation Levels of Learners During the COVID-19 Pandemic Process. In Handbook of Research on Emerging Pedagogies for the Future of Education: Trauma-Informed, Care, and Pandemic Pedagogy (pp. 191-208). IGI Global.

King, A., Evans, D. G., \& Blenkhorn, P. (2005). The evaluation of a web browser for blind people. In Pruski, A., Knops, H. (Eds.) Assistive Technology: From Virtuality to Reality (pp. 637-641). IOS Press, Amsterdam.

Kuniavsky, M. (2010). Smart things: ubiquitous computing user experience design. Elsevier.

Küçükönder, N., \& Kır, İ. (2014). Uzaktan eğitim uygulamalarında açık kaynak kodlu öğrenme yönetim sistemlerinin yeniden yaplandırılmasının incelenmesi [Examining the restructuring of open source learning management systems in distance education applications]. Kahramanmaraş Sütçü İmam Üniversitesi Sosyal Bilimler Dergisi, 13(1), 295304.

Lee, M., Han, S. H., Kim, H. K., \& Bang, H. (2015). Identifying user experience elements for people with disabilities. Proceedings of the 8th International Conference on Advances in ComputerHuman Interactions, Pohang, Korea. Access Adress: https://citeseerx.ist.psu.edu/viewdoc/download?doi=10.1.1.681.7575\&rep=rep1\&type=p df

Merriam, S. B. (2013). Nitel araştırma desen ve uygulama için bir rehber [A guide to qualitative research design and practice]. (Çev: S. Turan). Ankara: Nobel Akademik Yayıncllık.

Mills, G. E., \& Gay, L. R. (2016). Educational research competencies for analysis and applications. (11th Edition). Pearson.

Miles, M. B., Huberman A., M., \& Saldana, J. (2014). Qualitative data analysis: A methods sourcebook. (3rd Edition). SAGE Publication.

Mutlu, M. E. (2015). e-Öğrenme standartlarında yeni yönelimler [New directions in e-Learning standards]. Açıöğretim Uygulamaları ve Araştırmaları Dergisi, 1(4), 8-35.

Okur, M. R., \& Demir, M. (2019). Görme engelli öğrenenlerin eğitim yaşantısında karşılaştıkları sorunların belirlenmesi, açık ve uzaktan öğrenme alanı için çözüm yolları geliştirilmesi [Identifying the problems faced by visually impaired learners in their educational life, developing solutions for open and distance learning]. Açıöğretim Uygulamaları ve Araştırmaları Dergisi, 5(2), 49-62.

Özarslan, Y. (2016). Kullanıcı deneyimi ve tasarımının önemi [The importance of user experience and design]. H. Çalışkan ve M. R. Okur (Editörler), Kullanıcı deneyimi tasarımı (s. 2-17). Anadolu Üniversitesi Yayınları.

Özgüç, C. S., \& Cavkaytar, A. (2014). Teacher use of instructional technology in a special education school for students with intellectual disabilities: A Case Study. Turkish Online Journal of Qualitative Inquiry, 5(1), 51-65.

Park, K., Goh, T., \& So, H. J. (2014). Toward accessible mobile application design: developing mobile application accessibility guidelines for people with visual impairment. 한국 $\mathrm{HCI}$ 학회 학술대회, 31-38.

Petrie, H., Hamilton, F., King, N., \& Pavan, P. (2006, April). Remote usability evaluations with disabled people. In Proceedings of the SIGCHI conference on Human Factors in computing 
systems (pp. 1133-1141). Montreal, Canada. Access Adress: https://dl.acm.org/doi/abs/10.1145/1124772.1124942

Rosa, J. R. D. S., \& Valentim, N. M. C. (2020, October). Accessibility, usability and user experience design for visually impaired people: a systematic mapping study. In Proceedings of the 19th Brazilian Symposium on Human Factors in Computing Systems (pp. 1-10). Access Adress: https://dl.acm.org/doi/abs/10.1145/3424953.3426626

Santos, O. C., Couchet, J., \& Boticario, J. G. (2009, July). Personalized e-learning and e-mentoring through user modelling and dynamic recommendations for the inclusion of disabled at work and education. In Ninth IEEE International Conference on Advanced Learning Technologies (pp. 514-518), IEEE. Madrid, Spain. Access Adress: https://ieeexplore.ieee.org/document/5194291

Schrepp, M., Cota, M. P., Gonçalves, R., Hinderks, A., \& Thomaschewski, J. (2017). Adaption of user experience questionnaires for different user groups. Universal Access in the Information Society, 16(3), 629-640.

Sönmez, H. (2016). Engelli öğrencilerin sayısal ve sembol içerikli bir dersteki başarılarının incelenmesi: Anadolu Üniversitesi Açıöğgretim Sistemi örneği [Examining the success of students with disabilities in a numerical and symbolic course: Anadolu University Open Education System example]. Açıöğretim Uygulamaları ve Araştırmaları Dergisi, 2(4), 8-21.

Sözer, B., Özdamar, N., \& Pilanci, H. (2020). Yabancı dil öğrenimi için hazırlanan e-öğrenme ortamlarına ilişkin kullanılabilirlik araştırmalarının incelenmesi [Examination of usability studies on e-learning environments prepared for foreign language learning]. Açıöğretim Uygulamaları ve Araştırmaları Dergisi, 6(4), 174-207.

Şahin-İzmirli, Ö., Dönmez, O., \& Kabakç-Yurdakul, I. (2011). Üniversite Web Sayfalarının Gezinim Kolaylaştırıcıları Açısından İncelenmesi: Türkiye Örneklemi [Examining University Web Pages in Terms of Navigation Facilitators: The Sample of Turkey]. 5. Uluslararası Bilgisayar ve Öğretim Teknolojileri Sempozyumu. Fırat Üniversitesi, Elazı̆g.

Şenel, S. (2015). Görme engelli öğrencilerin üniversite giriş sınavı deneyimleri [University entrance exam experiences of visually impaired students]. Hacettepe Journal of Educational Research, 1(1), 1-17.

Tanyeri, U., \& Tüfekçi, A. (2010, Kasım). Bir yükseköğretim uzaktan eğitim programının görme engellilerin kullanımı açısından değerlendirilmesi: GÜUEP örneği [Evaluation of a higher education distance education program in terms of the use of the visually impaired: GUUEP example]. In International Conference on New Trends in Education and Their Implications Antalya, Turkey. Access Adress: http://www.iconte.org/FileUpload/ks59689/File/254.pdf

Yıldırım, A., \& Şimşek, H. (2013). Sosyal bilimlerde nitel araştırma yöntemleri [Qualitative research methods in the social sciences]. (9. Baskı). Ankara: Seçkin Yayıncılık.

YÖK (2021). Yükseköğretim Bilgi Yönetim Sistemi. Engelli Öğrenci Sayıları Raporu [Higher Education Information Management System. Disabled Student Numbers Report]. Erişim Adresi: https://istatistik.yok.gov.tr/

Yusril, A. N. (2020). E-accessibility analysis in user experience for people with disabilities. Indonesian Journal of Disability Studies, 7(1), 107-109. 
Ethics committee approval for this study was obtained from Anadolu University Social and Human Sciences Scientific Research and Publication Ethics Committee, dated 03/11/2020 and protocol number 60323.

\section{Statement of Contribution of Researchers to the Article:}

1st author contribution rate: $35 \%$

2nd author contribution rate: $35 \%$

3rd author contribution rate: $30 \%$

Conflict of Interest Statement:

There is no conflict of interest.

Statement of Financial Support or Acknowledgment:

No financial support was received from any institution for this study. 


\title{
Açık ve Uzaktan Öğrenmede Özel Gereksinimli Öğrencilerin Kullandıkları Web Sayfası ve Öğrenme Ortamına Yönelik Kullanıcı Deneyimlerinin ve Gereksinimlerinin İncelenmesi: Anadolu Üniversitesi Örneği*
}

\author{
Muhammet Recep OKUR $^{* *} \quad$ Hakan KILINÇ⿻*
}

Gizem YILDIZ****

\begin{abstract}
Öz. E-öğrenme sistemleri esnek yapısıyla özel gereksinimli öğrenciler için zamandan ve mekândan bağımsız öğrenme ortamları sunmaktadır. Bu ortamların özel gereksinimli öğrenciler için etkili olabilmesinde onların bireysel gereksinimlerini dikkate alan tasarımlar kritik role sahiptir. Bu araştırmanın amacı Türkiye'de özel gereksinimli üniversite öğrencilerinin büyük kısmına hizmet sunan Anadolu Üniversitesi Açıöğretim Sistemi "Engelsiz Açıköğretim Fakültesi (AÖF)" web sayfası ve çevrimiçi öğrenme ortamı olarak "e-Kampüs" sistemine yönelik kullanıcı deneyimlerinin belirlenmesidir. Bu bağlamda destek gereksinimlerinin, güçlüklerin ve çözüm önerilerinin ortaya konması çalışma amaçları arasındadır. Bu amaç doğrultusunda çalışmada nitel ve nicel veri toplama tekniklerinin işe koşulduğu durum çalışması deseni kullanılmıştır. Araştırmanın nicel aşamasına 9513 özel gereksinimli öğrenci, nitel aşamasına 20 görme yetersizliği olan öğrenci olmak üzere toplam 9533 öğrenci katılmıștır. Araștırma bulgularına göre özel gereksinimli öğrenciler kullandıkları web sayfası ve e-Kampüs sisteminin kullanımının kolay olduğunu, aradıkları içerikleri kolaylıkla bulabildiklerini, web sayfasından diğer hizmetlere (AKADEMA, Otomasyon vb.) erişebildiklerini ve faydalı içerikler (önlisans ve lisans programları) sunulduğunu bildirmiştir. Öte yandan güçlük yaşanan konular arasında mobil uygulama giriş ekranını kullanımı, çağrı merkezine erişimde ve e-Kampüs'te bazı içeriklere erişim gibi durumlara yer verilmiştir. Görme yetersizliği olan katılımcılar canlı derslere erişimin kolaylaştırılması, çevrimiçi sınavlarda metinlerin büyütülmesi ve ek süre verilmesi, giriş sayfasına sesli yönlendirmelerin eklenmesi ve sesli anlatımların artırılması konularına ilișkin gereksinimler noktasında destek talep etmişlerdir. Çalışmada katılımcıların gereksinim duyduğu bu destek alanları ve sözü edilen güçlüklerin giderilmesine yönelik çözüm önerileri bulgular ve ilgili alanyazın temelinde tartışılmıştır.
\end{abstract}

Anahtar Kelimeler: Açık ve uzaktan öğrenme, özel gereksinimli öğrenci, kullanıcı deneyimi, erişilebilirlik.

\footnotetext{
* Bu çalışma için etik kurul izni 03/11/2020 tarih ve 60323 protokol sayılı Anadolu Üniversitesi Sosyal ve Beşeri Bilimler Bilimsel Araştırma ve Yayın Etiği Kurulu'ndan alınmıştır.

** Orcid ID: https://orcid.org/0000-0003-2639-4987, Doç. Dr., Anadolu Üniversitesi, Türkiye, mrokur@gmail.com

*** Orcid ID: https://orcid.org/0000-0002-4301-1370, Dr., Anadolu Üniversitesi, Türkiye, hakankilinc@anadolu.edu.tr

**** Orcid ID: https://orcid.org/0000-0003-2693-6264, Dr., Anadolu Üniversitesi, Türkiye, 88.gizemyildiz@gmail.com

Okur, M. R., Kılınç, H., \& Ylldız, G. (2021). Examination of User Experiences and Needs for the Web Page and Learning Environment Used by Students with Special Needs in Open and Distance Learning: The Case of Anadolu University. Sakarya University Journal of Education, 11(2), 327-356. doi: https://doi.org/10.19126/suje.930534
} 


\section{GİRIŞ}

Özel gereksinimli öğrenci gelişimsel ve bireysel özellikleri nedeniyle eğitim yeterlilikleri açısından akranlarından anlamlı düzeyde farklılık gösteren öğrencileri tanımlar. Bu grup içerisinde işitme yetersizliği, görme yetersizliği, ortopedik yetersizliği, gelişimsel yetersizliği, süreğen hastalığı ve diğer yetersizlikleri olan bireyler yer alır (Heward vd., 2006). Eğitim sürecinde yetersizliklerinin çoğu zaman engele dönüştüğü özel gereksinimli öğrenciler eğitimde açıklık anlayışıyla çevrimiçi öğrenme dinamiklerini gözeten, zamandan ve mekândan bağımsız bu e-öğrenme sistemiyle, pek çok engeli aşabilmektedir. Anadolu Üniversitesi 1982 yılından beri açık ve uzaktan eğitim sistemiyle milyonlarca öğrenci için eğitimi erişilebilir kılmaktadır. Açıköğretim Sistemi e-öğrenme sistemlerinin esnek ve bireyselleştirilebilir yapısını kullanarak tüm öğrenciler tarafından erişilebilir öğrenme ortamları tasarlamaktadır. Bu durum özel gereksinimli öğrenciler için önem taşır ve Anadolu Üniversitesi’nin açık ve uzaktan eğitim sisteminin hedef kitlelerinden biri de özel gereksinimli öğrencilerdir.

Anadolu Üniversitesi Açlköğretim Sisteminde öğrenci merkezli yürütülen öğrenme sürecinde hazırlanan tüm eğitim-öğretim materyalleri öğrencilerin kendi kendilerine öğrenebilmesine yönelik tasarlanmaktadır (Sönmez, 2016). Özel eğitimde öğrenmeöğretme süreçleri de benzer şekilde öğrenci merkezlidir ve materyaller, yöntem ve teknikler, içerikler öğrenci gereksinimlerine göre bireyselleştirilir. Bu doğrultuda Anadolu Üniversitesi Açıöğretim Sistemi özel gereksinimli öğrencilerin yetersizlik gruplarına ve gereksinimlerine göre hizmetler sunmayı hedeflemektedir. Bu durum "esnek öğrenme" ile başlayan sistemin günümüzde "akıllı esnek öğrenme" modeliyle devam etmesinde açık bir şekilde görülebilmektedir. Esnek öğrenme, öğrenenlerin kişisel gereksinimleri ve tercihleri doğrultusunda öğrenme sürecini bireyselleştirmede farklı seçeneklerin oluşturulduğu öğrenme sistemidir (Demetriadis ve Pombortsis, 2007; Güler, 2018). Esnekliğin boyutları Casey ve Wilson (2005) tarafından şu şekilde belirtilmektedir; zaman, içerik, giriş koşulları, öğrenme yaklaşımı ve kaynakları, lojistik ve dağıtım.

Başarılı bir esnek öğrenme sistemi, öğrenmenin aktif olarak desteklendiği ortamı yaratabilmek için sistematik planlama, tasarlama, geliştirme ve değerlendirme basamaklarını içermelidir (Güler, 2018). Geliştirme ve değerlendirme basamağı sürecin aktif olarak güncellenmesi, izlenmesi, sorunların tespiti ve giderilmesi ile yeniden yapılandırılması gibi döngülere işaret eder. Öğrenme sürecini değerlendirmek; izleme, veri kaydetme ve ilerlemeleri görme, sorunları belirleme ve iyileştirme çalışmalarına hizmet eder. Buna göre Açıöğretim Sisteminin öğrenme sürecinin geliştirilmesi sistemin kullanıcıları ve paydaşları tarafından değerlendirilerek incelenebilir.

Özel gereksinimli öğrenciler için bu geliştirme ve değerlendirme basamakları çok daha fazla önem arz etmektedir. Öyle ki Açıköğretim Sisteminin kullanıcıları tarafından değerlendirilmesi erişilebilirlik, kullanıcı dostu tasarım, iyi yapılandırılmış bir içerik, öğrenen merkezli yaklaşım, uygun ücret gibi parametrelerle ölçülebilmektedir (Güler, 2018; Khan, 2003). Öte yandan bu parametrelerin özel gereksinimli öğrenciler açısından 
düşünüldüğünde normal gelişim gösteren öğrencilere kıyasla çok daha önemli olabileceği bilinmektedir (Edyburn, 2001; Özgüç ve Cavkaytar, 2014; Sani-Bozkurt, 2017). Dolayısıyla özel gereksinimli öğrencilerin Açıöğretim Sisteminden etkin bir şekilde faydalanabilmelerinde kullanıcı deneyimlerinin, kendi gereksinimlerinin, tercihlerinin ve yaşadıkları güçlüklerin belirlenmesi kritik rol oynamaktadır.

Kullanıcı deneyimi ürün ya da hizmetin kullanıcı ile arayüz vasıtasıyla ilişkilendiği tüm durumları ifade eder (Hassenzahl, 2014; Özarslan, 2016). Günümüzde kullanıcılar tarafından daha çok web sayfalarının arayüzleri üzerinden sunulan hizmetler kullanılmaktadır. Ürün ya da hizmetlerin tek başına sunumu artık yetersiz kalmış, kullanıcıların istek ve ihtiyaçlarını karşılanması amacıyla kullanıcıların duygu ve düşünceleri gibi deneyimleri de tasarımcılar tarafından ele alınan konular haline gelmiştir. Sonuç olarak kişinin bir ürün ya da hizmetle etkileşime girdiğinde oluşan algılarının tamamı kullanıcı deneyimi olarak değerlendirilmektedir (Kuniavsky, 2010; Özarslan, 2016). Kullanıcı deneyimi sonunda hedeflenen bir hizmetin kullanıcı tarafından beğenilmesi, kolaylığı, erişilebilirliği, verimliliği ve kullanımı sonunda yarar sağlamasıdır. İhtiyaçlar karşılanırken alınan hizmetlerde olumlu kullanıcı deneyimleri gerçekleştirildiği çoğu zaman fark edilmez, gerektiğinde tekrar deneyimlenir (Baird ve Fisher, 2005; Kuniavsky, 2010; Özarslan, 2016). Ancak olumsuz bir kullanıcı deneyimi uzun süre hatırlanır, başka kullanıcılarla paylaşılır ve sonraki tercihleri etkiler. Sürdürülebilir kullanıcı memnuniyeti oluşturmak ve hizmetlerin etkili ve verimli bir şekilde amacına ulaşmasını sağlamak için kullanıcı deneyimi oldukça önemlidir (Özarslan, 2016). Özel gereksinimli bireylerin kullanıcı olduğu hizmetler söz konusu olduğunda kullanıcı deneyimi daha bireysel hale gelmektedir.

Özel gereksinimli bireylerin yetersizliğine bağlı olarak özel gereksinimleri bulunur. Dolayısıyla bu bireylerin kullanıcı deneyimlerinin de toplumun diğer kesimine kıyasla özelleştiğini söylemek mümkündür (Henry vd., 2014; Rosa ve Valentim, 2020; Yusril, 2020). Bu durum sunulacak hizmetlerin onlara özel tasarlanmasını gerekli kılar. Bu bağlamda özel gereksinimli bireylerin kullandığı dijital öğrenme ortamlarının tasarımı bireylerin yetersizlik türlerine, bireysel farklılıklarına ve gereksinimlerine göre geliştirilmelidir. İlgili alanyazında, öğrenenlerin e-öğrenme ortamları kullanıcı deneyimlerini inceleyen araştırmalar (Emre, Akadal ve Gülseçen, 2018; Küçükönder ve Kır, 2014; Mutlu, 2015; Sözer, Özdamar ve Pilancı, 2020) e-öğrenme ortamlarında sunulan hizmetlerin daha verimli olabilmesi için kullanıcı deneyimlerinden faydalanmanın önemini vurgulamaktadır. Bu noktada özellikle de kullanıcılar ile bilgi paylaşma işlevini yerine getiren Web sitelerin, kullanılabilir olması ve kullanıcıların ihtiyaçlarına doğru cevapları verebilmesi için kullanıcı deneyimlerine başvurmak gerektiği ifade edilmektedir (Durmuş ve Çă̆lltay, 2012; Emre vd., 2018). Öte yandan özel gereksinimli öğrencilerin e-öğrenme sistemlerini nasıl kullandıkları, ne gibi desteklere gereksinim duydukları, onlara özel e-öğrenme ortamlarının nasıl olması gerektiğine ilişkin sınırlı sayıda araştırma mevcuttur. Bu konu üzerine gerçekleştirilmiş olan çalışmalar, erişilebilirliğin sadece teknik standartları ve yönergeleri takip etmekle sınırlı olmadığını, e-öğrenmenin teknolojiden çok daha fazlası olduğunu ve özel 
gereksinimli bireyler için e-öğrenmede evrensel öğrenme-öğretim tasarım ilkelerinin kullanıcı deneyimlerinden de faydalanmak suretiyle dikkat alınması gerektiğini vurgulamaktadır (Bühler ve Fisseler, 2007; Petrie vd., 2006; Santos, Couchet ve Boticario, 2009; Yusril, 2020). Bununla birlikte e-öğrenme sürecinde erişilebilirlik ve kullanılabilirlik değerlendirmeleri yapılırken özel gereksinimi olan ve olmayan tüm bireyleri kapsayıcı, tutarlı değerlendirme metodolojilerinin işe koşulması önerilmektedir (Cooper, Colwell ve Jelfs, 2007). Özel gereksinimli bireylerin kullanıcı deneyimi elementlerini inceleyen bir çalışmada ürün ve hizmetlerin kullanılabilirliğinin bu hizmetlerin bireysel özellikler ve gereksinimlere göre tasarlanmasına bağlı olduğu ifade edilmiştir (Lee vd., 2015). Özel gereksinimli öğrencilerin (görme yetersizliği olan) öğrenme sistemlerini kullanabilmeleri konusunda gerçekleştirilen bir diğer çalışmada ise erişilebilirlik, kullanılabilirlik ve kullanıcı deneyimi unsurlarının öğrenme sistemlerinin kalitesini artırabilmek için önemli unsurlar olduğu vurgulanarak, bu sayede ekran büyüklüğü, buton biçimleri, renk yoğunluğu gibi bazı öğelerin daha fazla geliştirilebileceği belirtilmiştir (Rosa ve Valentim, 2020).

Schrepp vd. (2017) kullanıcı deneyimlerine başvurmanın farklı kullanıcı grupları için uygulanabilir olduğunu, böylelikle kullanılan sistemlerin daha verimli olabileceğini vurgulamıştır. $\mathrm{Bu}$ noktada kullanıcı deneyimlerine başvurma sürecinde kullanılan araçların; dil, anlama düzeyi gibi unsurlar bağlamında hedef kitleye uygun olması gerektiğinin de altı çizilmiştir. Bununla birlikte bir Web sitesinin erişilebilir olabilmesi için özel gereksinimli bireylere de hitap etmesi gerektiği ifade edilmiştir. Bunun yanı sıra King, Evans ve Blenkhorn (2005) tarafından gerçekleştirilen bir çalışmada özel gereksinimli bireyler açısından Web sitelerinin kullanılabilirlik durumlarının oldukça önemli bir nokta olduğu vurgulanmıştır. Kullanılabilirlik unsurunun temel dayanakları ise etkililik, verimlilik ve memnuniyettir (ISO, 2000). Bu noktada Okur ve Demir (2019) tarafından gerçekleştirilen bir çalışmada, özel gereksinimli (görme yetersizliği olan) bireylerin Web sitesi gibi öğrenme sürecinde kullandıkları sistemlerin kullanılabilirliğinin incelenmesi gerektiği, bu noktada kullanıcıların ihtiyaçlarının belirlenebilmesi için kullanıcı deneyimlerine başvurulması gerektiği ifade edilmiştir.

Hem özel eğitim hem de açık ve uzaktan eğitim alanyazınında belirtildiği gibi özel gereksinimli öğrencilerin eğitiminde esas olan öğrenme sürecinin bireyselleştirilmesidir (Carneiro vd., 2015; Cho, 2021; Park vd., 2016; Yusril, 2020). Açıöğretim Sisteminde var olan özel gereksinimli öğrencilerin sistemi kullanma deneyimlerinin belirlenmesi, sistemi kullanırken yaşadıkları sorunların belirlenmesi ve işleyen sistemin var olan durumunun betimlenmesi ile özel gereksinimli öğrencilerin sistemi kullanmaya yönelik gereksinim ve tercihlerinin ortaya konulması; hem özel gereksinimli öğrencilerin eğitim haklarının gözetilmesi hem alan uygulamalarının iyileştirilmesi hem de Açıköğretim Sisteminin temel prensibi olan "esnek öğrenme" sürecinin değerlendirilmesi açısından gereklilik olarak karşımıza çıkmaktadır. Bununla birlikte 2019-2020 eğitim-öğretim dönemi itibariyle Türkiye'de yükseköğrenim gören özel gereksinimli öğrenenlerin sayılarının 51.647 olduğu ve bunun da 38.302'sinin Anadolu Üniversitesine kayıtlı olduğu (YÖK, 2021) göz önüne alındığında, bu çalışmadan elde edilecek olan sonuçların, 
özel gereksinimli öğrencilerin öğrenme sistemlerini kullanabilme durumlarının tespit edilmesi ve yaşanan olumsuzlukların belirlenerek giderilebilmesi açısından da önem taşıdığı ifade edilebilir. Anadolu Üniversitesine kayıtlı olan özel gereksinimli öğrencilerin en yoğun olarak kullandıkları hizmetler "Engelsiz AÖF" web sayfası ve "ANADOLUM e-Kampüs Sistemi” olması nedeniyle çalışma kapsamında bu sistemlere yönelik kullanıcı deneyimleri ele alınmıştır.

$\mathrm{Bu}$ doğrultuda çalışmanın temel amacı Anadolu Üniversitesi Açıöğretim Sisteminde kayıtlı özel gereksinimli öğrencilerin Engelsiz AÖF web sayfası ve e-Kampüs sistemine yönelik kullanıcı deneyimlerinin belirlenmesidir. $\mathrm{Bu}$ temel amaç kapsamında kullanıcıların destek gereksinimlerin ve karşılaştıkları güçlüklerin belirlenmesi ile bu gereksinimlerin karşılanmasına yönelik çözümlerin üretilmesi hedeflenmiştir. Çözüm önerileri araştırma bulguları ve alanyazın temelinde oluşturulmuştur. Bu doğrultuda aşağıdaki sorulara yanıt aranmaktadır:

1. Özel gereksinimli öğrencilerin Engelsiz AÖF web sayfasına ilişkin kullanıcı deneyimleri, nelerdir?

2. Özel gereksinimli öğrencilerin e-Kampüs sistemine ilişkin kullanıcı deneyimleri nelerdir?

3. Özel gereksinimli öğrencilerin engelsiz AÖF web sayfası ve e-Kampüs sisteminde yaşadıkları güçlüklere yönelik çözüm önerileri nelerdir?

\section{YÖNTEM}

\section{Araştırma Modeli}

Bu araştırmada, Anadolu Üniversitesi Açıköğretim Sisteminde kayıtlı özel gereksinimli öğrencilerin engelsiz AÖF web sayfasına ve ANADOLUM e-Kampüs sistemine ilişkin kullanıcı deneyimlerini, karşılaştıkları güçlükleri ve destek gereksinimlerini belirlemek üzere durum çalışması deseni kullanılmıştır. Durum çalışması deseni, bir durumun derinlemesine araştırılmasını ifade eder. Bir kurum, bir program, bir hizmet, bir sistem durumlara örnek oluşturabilir (Mills ve Gay, 2016; Yıldırım ve Şimşek, 2013). Bununla birlikte bu desende bir sistemin nasıl işlediği ve çalıştığı hakkında sistematik bilgi toplamak için çoklu veri toplama kullanılarak o sistemin derinlemesine incelenmesi sağlanmaktadır (Chmiliar, 2010). Bu çalışmada Açıöğretim sistemine kayıtlı özel gereksinimli öğrencilerin sistemi kullanma durumları hem nicel hem nitel veri toplama teknikleri işe koşularak betimlenmiştir. Bu kapsamda özel gereksinimli öğrencilerin Engelsiz AÖF web sayfası ve e-Kampüs sistemine ilişkin kullanıcı deneyimleri, yaşadıkları güçlükler ve gereksinim duydukları destekler açıklanmıştır. Çözüm önerileri yarı yapılandırılmış görüşmelerde katılımcılardan elde edilen bulgular ve alanyazın doğrultusunda oluşturulmuştur.

\section{Çalışma Grubu}

Araştırmanın çalışma grubunu Anadolu Üniversitesi Açıöğretim Sisteminde kayıtlı özel gereksinimli öğrenciler oluşturmaktadır. Bu çalışma grubu içerisinden amaçlı örnekleme 
tekniği ile katılımcılar belirlenmiştir. Araştırılan duruma ilişkin derinlemesine bilgi vereceği düşünülen, araştırma sorularını yanıtlamada en fazla destek sunabilecek örneklem seçimi amaçlı örnekleme olarak tanımlanmaktadır (Creswell, 2014). Katılımcılar amaçlı örnekleme türlerinden biri olan ölçüt örnekleme ile seçilmiştir. Ölçüt örnekleme ise amaca yönelik olarak önceden belirlenmiş, çalışma için önemli olan özelliklerin ölçüt olarak belirlendiği ve bu ölçütlerin tümünü sağlayan durumların seçildiği amaçlı örnekleme türüdür (Merriam, 2013; Yıldırım ve Şimşek, 2013).

Çalışmanın nicel veri toplama boyutunda araştırmanın evreni Türkiye'de tüm özel gereksinimli üniversite öğrencileridir. $\mathrm{Bu}$ evren içerisinden araştırma amacı doğrultusunda amaçlı örneklemeyle Anadolu Üniversitesi Açıöğretim Sisteminde kayıtlı tüm özel gereksinimli öğrencileri seçilmiştir. Bu örneklem içerisinden de ölçüt örneklemeyle işitme yetersizliği, görme yetersizliği, ortopedik yetersizliği, süreğen hastalığı olan ve diğer yetersizlik türleri bulunan toplam 9513 öğrenci anket uygulamasına katılmıştır. Nicel boyutta katılımcıların seçilmesinde dikkat edilen ölçütler katılımcının herhangi bir yetersizliğe sahip olması (tanısı olması) ve Açıköğretim öğrencisi olmasıdır.

Araştırmanın nitel aşamasında ise derinlemesine bilgi toplayabilmek adına ekran başında yürütülen uzaktan eğitimde görme sorunları nedeniyle en çok güçlük yaşayan ve örneklemdeki en kalabalık grup ( $\mathrm{f}=723$ ) olan görme yetersizliği olan öğrencilerden veri toplanmıştır. Nitel aşamaya araştırma evreninden ölçüt örneklemeyle seçilen 20 görme yetersizliği olan açıköğretim öğrencisi katılmıştır. Nitel aşamadaki örneklemin oluşturulma ölçütleri \%80 ve üzeri görme yetersizliğine sahip olma ve açıköğretim öğrencisi olma şeklinde belirlenmiştir. Bu ölçütün belirlenmesinde görme yetersizliğinin derecesinin yüksek olması durumunda olası daha fazla sorunun gündeme gelecek olması göz önüne alınmıştır. Böylelikle gereksinimlerin ve güçlüklerin daha net tespit edileceği ve çözüm önerilerinin de kapsamlı sunulacağı öngörülmüştür. Nicel aşamaya katılan 9513 özel gereksinimli öğrenciye ek olarak nitel aşamaya katılan 20 görme yetersizliği olan öğrenci ile bu araştırmaya toplam 9533 özel gereksinimli öğrenci katılmıştır. Nicel aşamaya katılan 9513 öğrencinin demografik bilgileri Tablo 1'de sunulmuştur. Buna göre katılımcıların yaşları 18 ila 65 ve üzeri arasında değişmekte, \%43'ü kadın \%57'si erkek, \%8'si görme yetersizliği, \%3’ü işitme yetersizliği, \%4'ü ortopedik yetersizlik, \%4'ü süreğen hastalık sahibi olup \%81'i ise diğer yetersizlik grubundadır. 
Tablo 1

Nicel Aşama Katılımcılarının Demografik Bilgileri

\begin{tabular}{|c|c|c|}
\hline Değişkenler & Frekans & Yüzde \\
\hline \multicolumn{3}{|l|}{ Mezuniyet } \\
\hline Doktora & 44 & 1 \\
\hline Yüksek lisans & 473 & 4 \\
\hline Lisans & 5458 & 58 \\
\hline Lise & 3538 & 37 \\
\hline Toplam & 9513 & 100 \\
\hline \multicolumn{3}{|l|}{ Program Türü } \\
\hline Ön lisans & 5433 & 57 \\
\hline Lisans & 4080 & 43 \\
\hline Toplam & 9513 & 100 \\
\hline \multicolumn{3}{|l|}{ Yetersizlik Türü } \\
\hline Görme yetersizliği & 723 & 8 \\
\hline İşitme yetersizliği & 318 & 3 \\
\hline Ortopedik yetersizlik & 348 & 4 \\
\hline Süreğen hastalık & 399 & 4 \\
\hline Diğer yetersizlikler & 7725 & 81 \\
\hline Toplam & 9513 & 100 \\
\hline \multicolumn{3}{|l|}{ Cinsiyet } \\
\hline Kadın & 4047 & 43 \\
\hline Erkek & 5466 & 57 \\
\hline Toplam & 9513 & 100 \\
\hline
\end{tabular}

Diğer yetersizlik grubunda gelişimsel yetersizlik ve ruhsal hastalıklar, öğrenme güçlüğü, vücut sistemleriyle ilişkili çeşitli sağlık sorunları, kulak burun boğazla ilgili sağlık sorunları ile iç hastalıklara dayalı yetersizlikler yer almaktadır.

Nitel aşamada 20 görme yetersizliği olan öğrenciyle Açıköğretim fakültesi çağrı merkezi üzerinden telefon aracılığıyla yarı yapılandırılmış görüşmeler gerçekleştirilmiştir. Nitel aşamaya katılan görme yetersizliği olan öğrencilerin demografik bilgileri Tablo 2'de verilmiştir. Tablo 2'ye göre görüşmelere katılan görme yetersizliği olan öğrencilerin 10'u kadın, 10'u erkek, yaş aralığı 19-44 olup, 13'ü lise 7'si üniversite mezunudur. Açıköğretim sisteminde ise 14'ü önlisans 6'sı lisans öğrencisi olarak okumaktadır. 
Tablo 2

Nitel Aşama Katılımcılarının Demografik Özellikleri

\begin{tabular}{lll}
\hline Özellik & Değişken & Kişi sayısı \\
\hline Cinsiyet & Kadın & 10 \\
& Erkek & 10 \\
Yaş aralığı & Min. & 19 \\
& Max. & 44 \\
Mezuniyet & Ortalama & 32 \\
\hline \multirow{2}{*}{ Eğitim durumu } & Üniversite mezunu & 7 \\
& Lise mezunu & 13 \\
\hline \multirow{2}{*}{ Sürekli kullanılan araç } & Lisans öğrencisi & 6 \\
& Önlisans öğrencisi & 14 \\
& Beyaz baston & 7 \\
& Ekran okuyucu & 3 \\
& Büyüteç & 2 \\
\hline \multirow{2}{*}{ Canlı ders deneyimi } & Ek yazılım desteği & 8 \\
\hline
\end{tabular}

\section{Uygulama Süreci}

Uygulama aşamasında ilk olarak araştırmacılar tarafından geliştirilmiş olan "Açıköğretim Öğrencilerinin Engelsiz AÖF Web Sayfası ve ANADOLUM E-Kampüs Sistemi Kullanıcı Deneyimi Anketi” çevrimiçi ortamda katılımcılara sunulmuş 9513 özel gereksinimli öğrenci tarafından doldurulmuştur. Anket doldurma aşaması sona erdikten sonra Açıköğretim sistemine kayıtlı özel gereksinimli öğrenciler arasından gönüllü ve ulaşılabilir 20 görme yetersizliği olan bireyle telefon aracılı̆̆ıyla yarı yapılandırılmış görüşmeler yapılmıştır. Görüşmeler Eskişehir ilindeki katılımcılarla yüz yüze, şehir dışından katılan katılımcılarla video konferans aracılığıyla yapılması planlanmış olmasına karşın pandemi nedeniyle tüm görüşmeler telefon ile yürütülmüştür. Görüşmeler Anadolu Üniversitesi Açıköğretim Çağrı Merkezinde çağrı sistemi üzerinden kayıt altına alınmış, her bir görüşmede çalışmanın amacı açıklanarak sesli onay alınmıştır.

\section{Veri Toplama Araçları}

$\mathrm{Bu}$ çalışma için etik kurul izni 03/11/2020 tarih ve 60323 protokol sayılı Anadolu Üniversitesi Sosyal ve Beşeri Bilimler Bilimsel Araştırma ve Yayın Etiği Kurulu'ndan alınmıştır. Araştırmada hem nitel hem nicel veri toplama araçları kullanılmıştır. Nitel 
veri toplama aracı olarak yarı yapılandırılmış görüşme formu durum çalışmasında katılımcıların bireysel görüşlerine başvurmada kullanılmıştır. Görüşme "bir kişinin kendini bir ya da birden fazla kişiye, sosyal olgularla ilişkili deneyimler, algılar, görüşler ve davranışlar hakkında sorular yöneltmekle, bu kişilerin ise kendilerini bu sorulara yanıt sağlamakla sınırladı̆̆ı sohbet” şeklinde tanımlanmaktadır (Boeije, 2010). Yarıyapılandırılmış görüşme görüşmecinin bazı temel sorularla görüşmeye başladı̆̆ı, görüşme esnasında soruların yanıtlara göre detaylandırıldığı görüşme türüdür (Creswell, 2014). Bu araştırmada özel gereksinimli bireylerin deneyimlerinin derinlemesine incelenebilmesi için yarı yapılandırılmış görüşme tekniği tercih edilmiştir. Görüşme formu öğrencilerin Engelsiz AÖF ve ANADOLUM E-Kampüs sistemini kullanırken yaşadıkları deneyimler, güçlükler ve çözüm önerilerini irdeleyen, araştırmacılar tarafından geliştirilen beş açık uçlu sorudan oluşmaktadır.

$\mathrm{Bu}$ aşamada yine katılımcıların deneyimlerini belirlemek üzere nicel veri toplama aracı olarak anket tekniği kullanılmıştır. Anket, araştırma problemlerinin çözümlenmesinde kullanılacak bilgilerin toplanmasında kullanılan, planlı ve standart biçimde bilgi almak için geliştirilmiş sormaca tekniğini ifade eder (Creswell, 2014; Mills ve Gay, 2016). Çalışmada özel gereksinimli öğrencilerin Açıöğretim sistemi ve e-Kampüse ilişsin kullanıcı deneyimini, karşılaştıkları güçlükleri ve gereksinimleri belirlemede araştırmacılar tarafından geliştirilen "Açıköğretim Öğrencilerinin Engelsiz AÖF Web Sayfası ve ANADOLUM E-Kampüs Sistemi Kullanıcı Deneyimi Anketi” kullanılmıştır.

\section{Anket Geliştirme Süreci}

Anderson (1990) anket geliştirme sürecini Şekil 1'de de görüldüğü üzere dört aşamada ele almaktadır; (1) Problemi Tanımlama: Amaç ve soru belirleme, (2) Madde Yazma: Taslak form oluşturma, (3) Uzman Görüşü Alma: Ön Uygulama formu oluşturma ve (4) Ön uygulama, ankete son şeklini verme. Bu araştırmada kullanılan anketin amacı, özel gereksinimli öğrencilerin Engelsiz AÖF web sayfasına ve ANADOLUM e-Kampüs sistemine ilişkin kullanıcı deneyimlerini, yaşadıkları güçlükleri ve gereksinimlerini belirlemektir. Anket maddeleri oluşturulurken 20 alan uzmanının görüşleri, özel eğitim ve Açıöğretim disiplinleriyle ilgili alanyazın ve Casey ve Wilson'un (2005) esneklik boyutları dikkate alınmıştır. Bu süreçte, özel eğitim ve Açıköğretim disiplinleriyle ilgili alanyazın dikkate alınarak oluşturulan anket maddeleri, alan uzmanlarının görüşlerine sunulmuş ve kendilerinden gelen dönütler neticesinde kapsam geçerliği ve görünüş geçerliğine ilişkin düzenlemeler yapılmıştır. Düzenlemeler tamamlandıktan sonra madde sayısının yaklaşık iki katı kadar bir grupla yapılan pilot uygulama ile maddelerin anlaşılırlığı, işlerliği ve anketin doldurulma süresi belirlenmiştir. Anket maddeleri 3'li likert tipinde "Katılıyorum-3", "Kararsızım-2", ve "Katılmıyorum-1" seçenekleriyle yanıtlanmıştır.

Anket Engelsiz AÖF web sayfasının kullanıcı deneyimleri bölümü 11 madde, e-Kampüs Sistemi kullanıcı deneyimi bölümü 19 madde olmak üzere toplam 30 maddeden oluşmaktadır. 


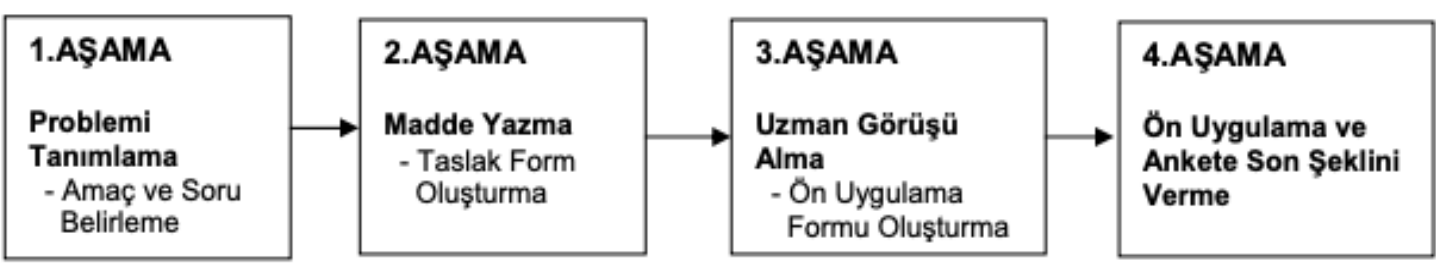

Şekil 1. Anket Geliştirme Süreci (Anderson, 1990)

\section{Verilerin Analizi}

Görüşmelerden elde edilen nitel veriler içerik analiziyle, anket verileri ise betimsel istatistik ile analiz edilmiştir. İçerik analizi; ses kaydının dökümü, verileri düzenleme ve analize hazırlama, bütün verileri okuma, verileri kodlama, temalar oluşturma, temaları ilişkilendirme ve temaları yorumlama basamaklarından oluşur (Creswell, 2014). Anket verilerinin ise SPSS 21 programı aracılığıyla betimsel istatistikleri hesaplanmıştır.

\section{Geçerlik ve Güvenirlik}

Anket maddeleri değerlendirmeye uygunluk açısından 20 uzmana gönderilmiştir. Uzman görüşleri açık ve kapalı uçlu sorulardan oluşan uzman değerlendirme formuyla belirlenmiştir. Uzman dönütlerine göre Lawshe (1975) kapsam geçerliliği çalışmaları yürütülmüştür. Lawshe’ye (1975) göre tüm soru maddelerinin kapsam geçerlik oranları (KGO) ve anketin Engelsiz AÖF ile ANADOLUM E-Kampüs bölümlerine ilişkin kapsam geçerlik indeksleri (KGİ) hesaplanmıştır. Buna göre anket maddelerinin en düşük KGO değeri 0.9, en yüksek KGO değeri 1 olarak, Engelsiz AÖF ve ANADOLUM E-Kampüs bölümlerine ilişkin KGİ ise 0.98 olarak hesaplanmıştır. Ankete son hali verildikten sonra ön uygulama 100 kişiyle gerçekleştirilmiş ve ortalama cevaplanma süresi ile maddelerin anlaşılırlığı ve işlerliği incelenmiş, bazı maddeler anlaşılırlık açısından ifadeleri düzenlenmiştir.

Araştırmanın nitel aşamasında ise göre nicel araştırmalardaki iç geçerlik-dış geçerlik (internal-external validity) nitel araştırmalarda inandırıcılık (credibility) ve aktarılabilirlik (transferability) olarak, yine nicel araştırmalarda iç güvenirlik-dış güvenirlik (internal-external reliability) ise nitel araştırmalarda tutarlık (consistency) ve teyit edilebilirlik (confirmability) olarak karşımıza çıkmaktadır (Erlandson vd., 1993; Guba ve Lincoln, 1989). İnandırıcılık ve tutarlık aşamalarında görüşme formunun geliştirilmesinde, verilerin dökümü ve analizinde, bulguların sunumunda uzman görüşü alınmıştır. Aktarılabilirliği sağlamak üzere tüm nitel araştırma süreci zengin ve ayrıntılı şekilde betimlenmiş ve amaçlı örneklemeyle yeterli katılımcıya $(n=20)$ ulaşılmıştır. Son olarak teyit edilebilirliği sağlamak üzere ses kayıtları bağımsız bir uzman tarafından dinlenmiş ve dökümlerle kıyaslanmıştır. Ardından bağımsız uzman ile kodlama güvenirliği çalışması yürütülmüştür. Miles, Huberman ve Saldana (2014) uzlaşma öncesi kodlamalar arası tutarlılık katsayısı en az \%70 olmalıdır. Kodlama güvenirliği uzlaşma öncesinde \%87 hesaplanmış, ardından araştırmacılar ve bağımsız uzman bir araya 
gelerek farklı görüş bildirilen kodlar üzerinde uzlaşma sağlamış ve uzlaşma sonrası katsayı \%100 olarak hesaplanmıştır.

\section{BULGULAR}

Bu başlıkta ilk olarak anketten elde edilen nicel bulgulara ardından yarı yapılandırılmış görüşmelerden elde edilen nitel bulgulara yer verilmiştir. Nicel bulgular ise kendi içerisinde iki başlıkta ele alınmıştır. İlk olarak anketin birinci bölümünü oluşturan Engelsiz AÖF web sayfası kullanıcı deneyimleri, ikinci başlıkta ise anketin ikinci bölümü olan e-Kampüs sistemi kullanıcı deneyimleri verilmiştir.

\section{Özel Gereksinimli Öğrencilerin Engelsiz AÖF Web Sayfasına İlişkin Kullanıcı Deneyimleri}

Özel gereksinimli öğrencilerin Engelsiz AÖF web sayfası kullanımlarına ilişkin görüşlerinin belirlendiği anketin 11 maddelik ilk bölümüne verilen yanıtlar Tablo 3'te verilmiştir. Tablo 3'te yer alan her bir yetersizlik grubuna ilişkin anket sonuçları izleyen başlıklarda ayrı şekilde özetlenmiştir.

\section{Görme Yetersizliği Olan Öğrencilerden Elde Edilen Bulgular}

Tablo 3'te verilen betimsel istatistiklere göre görme yetersizliği olan öğrencilerin yarısından fazlası Açıöğretim Sisteminde (AÖS) tüm programların Engelsiz AÖF web sayfasından erişilebilir olduğunu (\%62), duyuruların zamanında yapıldığını (\%61), web sayfasında kılavuz ve yönergelerin erişilebilir olduğunu (\%60), web sayfasını kullanarak diğer hizmetlere erişebildiklerini (\%60), aradıkları içerikleri kolayca bulabildiklerini (\%59) ve başkasının yardımına ihtiyaç duymadan web sayfasına kayıt olabildiklerini ifade etmişlerdir. Bunun yanı sıra olumsuz görüşler arasında düşük bir oranla da olsa en yoğun belirtilen konular öğrenci işleri ve çağrı merkeziyle iletişim kurma (\%21) olmuştur. Görme yetersizliği olan öğrencilerin kararsız kaldıkları konular arasında ise AÖF kayıt koşullarının tüm yetersizlik gruplarını kapsaması (\%39) ile web sayfasında yetersizliği olan öğrencilere yönelik düzenlemelerin yeterli olması (\%37) en yüksek frekanslara sahiptir. 
Tablo 3

Katılımcıların Engelsiz AÖF Web Sayfasına İlişkin Anket Maddelerine Verdikleri Yanıtların Yüzdeleri

\begin{tabular}{|c|c|c|c|c|c|c|c|c|c|c|c|c|c|c|c|}
\hline \multirow{2}{*}{ Anket Maddesi } & \multicolumn{5}{|c|}{ Katılıyorum (\%) } & \multicolumn{5}{|c|}{ Kararsızım (\%) } & \multicolumn{5}{|c|}{ Katılmiyorum (\%) } \\
\hline & G & $\dot{I}$ & 0 & S & D & G & $\dot{I}$ & 0 & S & D & G & $\dot{I}$ & 0 & S & $\mathrm{D}$ \\
\hline $\begin{array}{l}\text { 1. AÖF kayıt koşullarının tüm yetersizlik gruplarını } \\
\text { kapsadığını düşünüyorum. }\end{array}$ & $\% 43$ & $\% 49$ & $\% 50$ & $\% 46$ & $\% 35$ & $\% 39$ & $\% 32$ & $\% 32$ & $\% 38$ & $\% 42$ & $\% 18$ & $\% 19$ & $\% 18$ & $\% 16$ & $\% 23$ \\
\hline $\begin{array}{l}\text { 2. Kayıt süresince ihtiyaç duyduğum anlarda } \\
\text { Açıöğgretim Sistemi öğrenci işleriyle iletişim } \\
\text { kurabiliyorum. }\end{array}$ & $\% 53$ & $\% 56$ & $\% 60$ & $\% 57$ & $\% 49$ & $\% 26$ & $\% 22$ & $\% 21$ & $\% 23$ & $\% 30$ & $\% 21$ & $\% 22$ & $\% 19$ & $\% 20$ & $\% 21$ \\
\hline $\begin{array}{l}\text { 3. İhtiyaç duyduğum anlarda çağrı merkezine } \\
\text { ulaşabiliyorum. }\end{array}$ & $\% 51$ & $\% 46$ & $\% 52$ & $\% 56$ & $\% 48$ & $\% 28$ & $\% 24$ & $\% 24$ & $\% 22$ & $\% 30$ & $\% 21$ & $\% 30$ & $\% 24$ & $\% 22$ & $\% 22$ \\
\hline $\begin{array}{l}\text { 4. Program tercihi yaparken tüm programlara ilișkin } \\
\text { bilgilere Engelsiz AÖF web sayfasından kolaylıkla } \\
\text { ulaşabiliyorum. }\end{array}$ & $\% 62$ & $\% 53$ & $\% 58$ & $\% 61$ & $\% 53$ & $\% 27$ & $\% 26$ & $\% 24$ & $\% 26$ & $\% 33$ & $\% 11$ & $\% 21$ & $\% 18$ & $\% 13$ & $\% 14$ \\
\hline $\begin{array}{l}\text { 5. Engelsiz AÖF sistemiyle ilgili yardıma ihtiyaç } \\
\text { duyduğumda AÖS destek birimine ulaşabiliyorum. }\end{array}$ & $\% 52$ & $\% 49$ & $\% 52$ & $\% 56$ & $\% 48$ & $\% 31$ & $\% 29$ & $\% 29$ & $\% 30$ & $\% 34$ & $\% 17$ & $\% 22$ & $\% 19$ & $\% 14$ & $\% 18$ \\
\hline $\begin{array}{l}\text { 6. Engelsiz AÖF sitesindeki duyuruların zamanında } \\
\text { yapıldığını düșünüyorum. }\end{array}$ & $\% 61$ & $\% 56$ & $\% 64$ & $\% 60$ & $\% 54$ & $\% 27$ & $\% 29$ & $\% 26$ & $\% 28$ & $\% 33$ & $\% 11$ & $\% 15$ & $\% 10$ & $\% 12$ & $\% 13$ \\
\hline $\begin{array}{l}\text { 7. Engelsiz AÖF web sayfasındaki kılavuzlara, } \\
\text { yönergelere vb. kolaylıkla erișebiliyorum. }\end{array}$ & $\% 60$ & $\% 55$ & $\% 62$ & $\% 61$ & $\% 54$ & $\% 27$ & \%28 & $\% 26$ & $\% 26$ & $\% 33$ & $\% 12$ & $\% 17$ & $\% 12$ & $\% 13$ & $\% 13$ \\
\hline $\begin{array}{l}\text { 8. Açıöğgretim sistemindeki istediğim bir programa } \\
\text { engelsizaof.anadolu.edu.tr adresinden başkasının } \\
\text { yardımına ihtiyaç duymadan kaydolabileceğimi } \\
\text { düşünüyorum. }\end{array}$ & $\% 58$ & $\% 52$ & $\% 63$ & $\% 62$ & $\% 55$ & $\% 32$ & $\% 31$ & $\% 25$ & $\% 29$ & $\% 34$ & $\% 10$ & \%17 & $\% 12$ & $\% 9$ & $\% 11$ \\
\hline $\begin{array}{l}\text { 9. Engelsiz AÖF web sayfasında aradığım içeriği } \\
\text { kolaylıkla bulabiliyorum. }\end{array}$ & $\% 59$ & $\% 53$ & $\% 60$ & $\% 60$ & $\% 54$ & $\% 28$ & $\% 29$ & $\% 26$ & $\% 28$ & $\% 35$ & $\% 13$ & $\% 18$ & \%14 & $\% 12$ & $\% 13$ \\
\hline $\begin{array}{l}\text { 10. Engelsiz AÖF web sayfasında } \\
\text { görme/işitme/ortopedik yetersizliği olan öğrencilere } \\
\text { özel yapılan düzenlemelerin yeterli olduğunu } \\
\text { düșunnüyorum. }\end{array}$ & $\% 51$ & $\% 46$ & $\% 55$ & $\% 49$ & $\% 47$ & \%37 & $\% 33$ & $\% 31$ & $\% 39$ & $\% 41$ & $\% 12$ & \%19 & $\% 14$ & $\% 12$ & $\% 12$ \\
\hline $\begin{array}{l}\text { 11. Engelsiz AÖF web sayfasını kullanarak diğer } \\
\text { hizmetlere (AKADEMA, e-Kampüs, öğrenci } \\
\text { otomasyonu, AÖS destek vb.) kolaylıkla giriş } \\
\text { yapabiliyorum. }\end{array}$ & $\% 60$ & $\% 57$ & $\% 63$ & $\% 64$ & $\% 55$ & $\% 30$ & $\% 29$ & $\% 23$ & $\% 26$ & $\% 34$ & $\% 10$ & \%14 & $\% 14$ & $\% 10$ & $\% 11$ \\
\hline
\end{tabular}

Not: G= Görme yetersizliği olanlar, İ= İşitme yetersizliği olanlar, $\mathrm{O}=$ Ortopedik yetersizliği olanlar, S= Süreğen hastalığı olanlar, D= Diğer yetersizlikler 


\section{İşitme Yetersizliği Olan Öğrencilerden Elde Edilen Bulgular}

Tablo 3'te görüldüğü gibi işitme yetersizliği olan öğrencilerin yarısından fazlası Engelsiz AÖF web sayfasını kullanarak diğer hizmetlere ulaşabildiğini (\%57), ihtiyaç anında Açıöğretim Sistemi öğrenci işleriyle iletişim kurabildiğini (\%56), web sayfasında duyuruların zamanında yapıldığını (\%56), web sayfasındaki kılavuz ve yönergelere kolaylıkla ulaşabildiğini (\%55) belirtmiştir. Çoğunluğun olumlu görüş bildirmesine karşın işitme yetersizliği olan öğrenciler arasında belirtilen güçlükler ise çağrı merkezine ulaşma (\%30), AÖS destek birimine ulaşma (\%22) ve yine öğrenci işleriyle iletişim kurma (\%22) üzerine yoğunlaşmaktadır. Dil ve iletişimde sorun yaşayan bu yetersizlik grubunda iletişimle ilişkili maddelere yönelik olumsuz görüşlerin diğerlerine kıyasla yüksek olduğu görülmektedir.

\section{Ortopedik Yetersizliği Olan Öğrencilerden Elde Edilen Bulgular}

Tablo 3'te görüldügü gibi ortopedik yetersizliği olan öğrenci grubunda Engelsiz AÖF web sayfası kullanıcı deneyimine ilişkin olumlu görüşler sırasıyla duyuruların zamanında yapılması (\%64), web sayfasında başkasının yardımına ihtiyaç duymadan bir program kayıt olunması (\%63), web sayfasını kullanarak diğer hizmetlere kolaylıkla erişim sağlanması (\%63), web sayfasındaki kılavuz ve yönergelere kolay erişim (\%62), web sayfasındaki içeriklerin kolaylıkla bulunması (\%60), öğrenci işleriyle iletişim kurulması (\%60) ve web sayfası üzerinden tüm programlara erişim sağlanması (\%58) konularında bildirilmiştir. Öte yandan ortopedik yetersizliği olan öğrencilerin çağrı merkezine ulaşımda güçlük yaşadıkları (\%24), öğrenci işleriyle iletişim (\%19) ve AÖS destek birimine erişimde (\%19) güçlük yaşadıkları görülmektedir.

\section{Süreğen Hastalığa Sahip Olan Öğrencilerden Elde Edilen Bulgular}

Tablo 3'e göre süreğen hastalığı olan öğrencilerin Engelsiz AÖF web sayfası kullanıcı deneyimlerinde en memnun oldukları konular web sayfasını kullanarak diğer hizmetlere giriş yapabilme (\%64), web sayfası üzerinden başkasının yardımına ihtiyaç duymadan bir programa kaydolma (\%62), web sayfasından tüm programlara, kılavuzlara ve yönergelere kolaylıkla erişebilme (\%61), web sayfasında aranan içeriği kolaylıkla bulabilme (\%60), web sayfasında duyuruların zamanın yapılması (\%60) şeklindedir. Süreğen hastalığı olan öğrencilerin de görme, işitme ve ortopedik yetersizliği olan öğrenciler gibi olumsuz görüş bildirdiği konular çağrı merkezine ulaşma (\%22) ve öğrenci işleriyle iletişim kurmada (\%20) yoğunlaşmaktadır.

\section{Diğer Yetersizliklere Sahip Olan Öğrencilerden Elde Edilen Bulgular}

Diğer yetersizlikler içerisinde zihin yetersizliği ve ruhsal hastalıklar, öğrenme güçlüğü, yaygın gelişimsel bozukluklar, kulak burun boğazla ilgili sağlık sorunları, sindirim sistemi, sinir sistemi, endokrin sistem, hematopoetik sistem gibi vücut sistemleriyle ilişkili çeşitli sağlık sorunları, iç hastalıklara dayalı yetersizlikler yer almaktadır. Bu yetersizlik arasında ise zihin yetersizliği, ruhsal hastalık ve yaygın gelişimsel bozukluklar tüm yetersizlik grupları arasında göz ardı edilebilecek kadar az sayıdadır. 
Dolayısıyla bu çalışmada "diğer yetersizlikler" seçeneğini işaretleyen katılımcıların çok büyük bir kısmının sağlıkla ilgili yetersizliklere sahip olduğu söylenebilir.

Tablo 3'te görüldügü gibi Açıöğretime kayıtlı özel gereksinimli \%81'ini oluşturan diğer yetersizlik grubunun yarısından fazlası başkasının yardıma ihtiyaç duymadan engelsizaof.anadolu.edu.tr adresinden istediği programa kaydolabileceğini (\%55), bu web sayfası üzerinden AKADEMA, e-Kampüs, otomasyon gibi diğer hizmetlere kolaylıkla erişebileceğini (\%55), aradığı kılavuz ve yönergeleri kolaylıkla bulabileceğini (\%54), aradığı içeriği kolaylıkla bulabileceğini (\%54), web sitesinden duyuruların zamanında yapıldığını (\%54) belirtmiştir. Diğer yetersizlik grubundaki öğrencilerin katılmadıkları görüşler arasında AÖF kayıt koşullarının tüm yetersizlik gruplarını kapsaması (\%23), ihtiyaç anında çağrı merkezine ulaşma (\%22), öğrenci işleriyle iletişim kurma (\%21), AÖS destek birimine ulaşma (\%18) konuları dikkat çekmektedir.

\section{Özel Gereksinimli Öğrencilerin ANADOLUM E-Kampüse İlişkin Kullanıcı Deneyimleri}

\section{Görme Yetersizliği Olan Öğrencilerden Elde Edilen Bulgular}

Tablo 4'e göre görme yetersizliği olan öğrencilerin $\% 60$ ’ ve üzerinin e-Kampüs sistemindeki öğrenme materyallerinin kolaylıkla indirilip kaydedilmesi (\%65), başkasına ihtiyaç duymadan e-Kampüse giriş yapılması (\%64), başkasına ihtiyaç duymadan derslere giriş yapılması (\%63), e-Kampüste yapılan duyuruların faydalı olması (\%61) ve e-Kampüs sistemi web sayfasının kullanımının kolay olması (\%60) görüşüne katıldığı görülmektedir. Görme yetersizliği olan bireylerin katılmadığı görüşler arasında en sık belirtilen konular dersleri yürüten öğretim elemanlarıyla iletişim kurma (\%18), AÖS destek biriminden destek alma (\%17), ders süreleri ve deneme sınavı için verilen sürelerin yeterli olması (\%14) şeklindedir.

\section{İşitme Yetersizliği Olan Öğrencilerden Elde Edilen Bulgular}

Tablo 4'e göre işitme yetersizliği olan öğrencilerin \%60'ı başkasının yardımına ihtiyaç duymadan e-Kampüse giriş yapabildiğini, \%59’u e-Kampüsteki derslere giriş yapabildiğini, \%57'si çevrimiçi sınavları tamamlayabildiğini, \%57'si derslerdeki öğrenme materyallerini kolaylıkla indirip kaydedebildiğini belirtmiştir. İşitme yetersizliği olan öğrencilerin \%27'si e-Kampüste dersin öğretim elemanlarıyla iletişim kuramadığını, \%20'si AÖS destek birimine kolayca ulaşamadığını, \%19'su ders sürelerinin yeterli olmadığını, \%19’u canlı derslerde öğrenme materyallerine erişemediklerini, yine \%19’u deneme sınavlarının sürelerinin yeterli olmadığını belirtmiștir.

\section{Ortopedik Yetersizliği Olan Öğrencilerden Elde Edilen Bulgular}

Tablo 4'te görüldüğü gibi ortopedik yetersizliği olan öğrencilerin \%67'si e-kampüse başkasının yardımı olmadan giriş yapabildiğini, \%66'sı çevrimiçi sınavları başkasının yardımı olmadan tamamlayabildiğini, \%66'sı ders materyallerini kolaylıkla indirip kaydedebildiğini, \%65'i e-kampüsteki derslere başkasının yardımı olmadan girebildiğini, \%63'ü e-kampüs duyurularının faydalı olduğunu, \%61'i web sayfasının kullanımının 
kolay olduğunu ve \%60’ı deneme sınavlarını başkasının yardımı olmadan yapabildiğini ifade etmiştir. Ortopedik yetersizliği olan öğrencilerin katılmadığı görüşler arasında en sık belirtilen konular ise şu şekildedir; e-kampüste dersin öğretim elemanlarıyla iletişim kurma (\%22), AÖS destek biriminden e-kampüsle ilgili destek alma (\%19), canlı derslerde soru-cevap için yeterli süre ayrılması (\%18) ve e-Kampüsteki derslerin sürelerinin yeterli olması (\%17). 
Tablo 4

Katılımcıların E-Kampüs Sistemine İlişkin Anket Maddelerine Verdikleri Yanıtların Yüzdeleri

\begin{tabular}{|c|c|c|c|c|c|c|c|c|c|c|c|c|c|c|c|}
\hline \multirow{2}{*}{ Anket Maddesi } & \multicolumn{5}{|c|}{ Katilıyorum (\%) } & \multicolumn{5}{|c|}{ Kararsızım (\%) } & \multicolumn{5}{|c|}{ Katılmıyorum (\%) } \\
\hline & G & $\dot{I}$ & 0 & S & $\mathrm{D}$ & G & İ & 0 & S & $\mathrm{D}$ & G & $\dot{I}$ & 0 & S & $\mathrm{D}$ \\
\hline $\begin{array}{l}\text { 1. E-Kampüste dersleri yürüten öğretim elemanlarıyla } \\
\text { kolaylıkla iletișim kurabiliyorum. }\end{array}$ & $\% 41$ & $\% 42$ & $\% 46$ & $\% 35$ & $\% 42$ & $\% 41$ & $\% 31$ & $\% 31$ & $\% 41$ & $\% 40$ & $\% 18$ & $\% 27$ & $\% 22$ & $\% 24$ & $\% 18$ \\
\hline $\begin{array}{l}\text { 2. E-Kampüs sisteminde sorun yaşadığımda AÖS destek } \\
\text { biriminden kolaylıkla destek alabiliyorum. }\end{array}$ & $\% 47$ & $\% 48$ & $\% 48$ & $\% 47$ & $\% 47$ & $\% 36$ & $\% 32$ & $\% 33$ & $\% 37$ & $\% 34$ & $\% 17$ & $\% 20$ & $\% 19$ & $\% 17$ & $\% 19$ \\
\hline $\begin{array}{l}\text { 3. E-Kampüste yapılan duyuruların faydalı olduğunu } \\
\text { düșünüyorum. }\end{array}$ & $\% 61$ & $\% 55$ & $\% 63$ & $\% 65$ & $\% 57$ & $\% 29$ & $\% 29$ & $\% 25$ & $\% 26$ & $\% 32$ & $\% 10$ & $\% 16$ & $\% 13$ & $\% 9$ & $\% 11$ \\
\hline $\begin{array}{l}\text { 4. E-Kampüsteki derslerin sürelerinin yeterli olduğunu } \\
\text { düşünüyorum. }\end{array}$ & $\% 52$ & $\% 53$ & $\% 53$ & $\% 53$ & $\% 49$ & $\% 34$ & $\% 28$ & $\% 30$ & $\% 32$ & $\% 38$ & $\% 14$ & $\% 19$ & $\% 17$ & $\% 15$ & $\% 13$ \\
\hline $\begin{array}{l}\text { 5. Canlı derslerde soru-cevap için yeterli süre ayrıldığını } \\
\text { düşünüyorum. }\end{array}$ & $\% 42$ & $\% 46$ & $\% 40$ & $\% 38$ & $\% 42$ & $\% 45$ & $\% 37$ & $\% 41$ & $\% 47$ & $\% 43$ & $\% 13$ & $\% 17$ & $\% 18$ & $\% 15$ & $\% 15$ \\
\hline $\begin{array}{l}\text { 6. E-Kampüste yapılan deneme sinavları için verilen } \\
\text { sürenin yeterli olduğunu düșünüyorum. }\end{array}$ & $\% 47$ & $\% 48$ & $\% 49$ & $\% 53$ & $\% 46$ & \%39 & $\% 33$ & $\% 34$ & $\% 34$ & $\% 40$ & $\% 14$ & \%19 & $\% 17$ & $\% 13$ & $\% 14$ \\
\hline $\begin{array}{l}\text { 7. Canlı derslerin etkileşimli bir şekilde yürütüldüğünü } \\
\text { düşünüyorum. }\end{array}$ & $\% 46$ & $\% 48$ & $\% 47$ & $\% 41$ & $\% 44$ & $\% 42$ & $\% 35$ & $\% 39$ & $\% 44$ & $\% 43$ & $\% 12$ & $\% 17$ & $\% 14$ & $\% 15$ & $\% 13$ \\
\hline $\begin{array}{l}\text { 8. Canlı derslerde kullanılan kütüphane, web sayfası, } \\
\text { pdfler, pptler, videolar, animasyonlar vb. öğrenme } \\
\text { materyallerine kolaylıkla erișebiliyorum. }\end{array}$ & $\% 50$ & $\% 48$ & $\% 54$ & $\% 51$ & $\% 48$ & $\% 37$ & $\% 33$ & $\% 30$ & $\% 37$ & $\% 39$ & $\% 13$ & \%19 & $\% 16$ & $\% 12$ & $\% 13$ \\
\hline $\begin{array}{l}\text { 9. Canlı derslerde kullanılan öğrenme materyallerinin } \\
\text { görme yetersizliği olan öğrencilere özel hazırlandığını } \\
\text { düșünüyorum. }\end{array}$ & $\% 45$ & $\% 44$ & $\% 50$ & $\% 45$ & $\% 44$ & $\% 43$ & $\% 41$ & $\% 34$ & $\% 43$ & $\% 44$ & $\% 12$ & $\% 15$ & $\% 16$ & $\% 12$ & $\% 12$ \\
\hline $\begin{array}{l}\text { 10. Canlı derslerde video, fotoğraf, animasyon gibi görsel } \\
\text { ve işitsel desteklerin kullanıldığını düșünüyorum. }\end{array}$ & $\% 46$ & $\% 47$ & $\% 48$ & $\% 45$ & $\% 46$ & $\% 42$ & $\% 36$ & $\% 38$ & $\% 44$ & $\% 43$ & $\% 12$ & $\% 17$ & $\% 14$ & $\% 11$ & $\% 11$ \\
\hline $\begin{array}{l}\text { 11. E-Kampüsteki derslerde verilen ödev teslim } \\
\text { sürelerinin uygun olduğunu düşünüyorum. }\end{array}$ & $\% 43$ & $\% 43$ & $\% 43$ & $\% 42$ & $\% 43$ & $\% 47$ & $\% 39$ & $\% 40$ & $\% 45$ & $\% 45$ & $\% 10$ & \%18 & \%17 & $\% 13$ & $\% 12$ \\
\hline
\end{tabular}

Not: G= Görme yetersizliği olanlar, İ= İşitme yetersizliği olanlar, $\mathrm{O}=$ Ortopedik yetersizliği olanlar, S= Süreğen hastalığı olanlar, D= Diğer yetersizlikler 
Tablo 4 (devam)

\begin{tabular}{|c|c|c|c|c|c|c|c|c|c|c|c|c|c|c|c|}
\hline \multirow{2}{*}{ Anket Maddesi } & \multicolumn{5}{|c|}{ Katılıyorum (\%) } & \multicolumn{5}{|c|}{ Kararsızım (\%) } & \multicolumn{5}{|c|}{ Katılmıyorum (\%) } \\
\hline & G & İ & 0 & S & D & G & İ & 0 & S & D & G & $\dot{I}$ & 0 & S & $\mathrm{D}$ \\
\hline $\begin{array}{l}\text { 12. E-Kampüsteki derslerde verilen ödevleri } \\
\text { gerçekleştirmek için sunulan yönergelerin yeterli } \\
\text { olduğunu düșünüyorum. }\end{array}$ & $\% 46$ & $\% 43$ & $\% 46$ & $\% 45$ & $\% 44$ & $\% 44$ & $\% 41$ & $\% 38$ & $\% 42$ & $\% 44$ & $\% 10$ & $\% 16$ & $\% 16$ & $\% 13$ & $\% 12$ \\
\hline $\begin{array}{l}\text { 13. E-Kampüste gerçekleştirilen sinavların uygulanma } \\
\text { biçiminin görme yetersizliği olan öğrenciler için } \\
\text { uygun olduğunu düşünüyorum. }\end{array}$ & $\% 48$ & $\% 47$ & $\% 50$ & $\% 47$ & $\% 45$ & $\% 41$ & $\% 38$ & $\% 34$ & $\% 41$ & $\% 44$ & $\% 11$ & $\% 15$ & $\% 16$ & $\% 12$ & $\% 11$ \\
\hline $\begin{array}{l}\text { 14. E-Kampüste gerçekleştirilen deneme sınavlarını } \\
\text { başkasının yardımına ihtiyaç duymadan } \\
\text { tamamlayabilirim. }\end{array}$ & $\% 55$ & $\% 52$ & $\% 60$ & $\% 64$ & $\% 53$ & $\% 33$ & $\% 30$ & $\% 26$ & $\% 27$ & $\% 37$ & $\% 12$ & $\% 18$ & $\% 14$ & $\% 9$ & $\% 10$ \\
\hline $\begin{array}{l}\text { 15. esinav.anadolu.edu.tr adresini kullanarak çevrimiçi } \\
\text { sınavları başkasının yardımına ihtiyaç duymadan } \\
\text { tamamlayabilirim. }\end{array}$ & $\% 60$ & $\% 57$ & $\% 66$ & $\% 68$ & $\% 57$ & $\% 30$ & $\% 29$ & $\% 22$ & $\% 22$ & $\% 33$ & $\% 10$ & $\% 14$ & $\% 12$ & $\% 10$ & $\% 10$ \\
\hline $\begin{array}{l}\text { 16. E-Kampüse başkasının yardımına ihtiyaç duymadan } \\
\text { giriş yapabilirim. }\end{array}$ & $\% 64$ & $\% 60$ & $\% 67$ & $\% 73$ & $\% 59$ & $\% 28$ & $\% 26$ & $\% 20$ & $\% 20$ & $\% 32$ & $\% 8$ & $\% 14$ & $\% 13$ & $\% 7$ & $\% 9$ \\
\hline $\begin{array}{l}\text { 17. E-Kampüste gerçekleștirilen derslere başkasının } \\
\text { yardımına ihtiyaç duymadan giriş yapabilirim. }\end{array}$ & $\% 63$ & $\% 59$ & $\% 65$ & $\% 73$ & $\% 58$ & $\% 28$ & $\% 26$ & $\% 23$ & \%19 & $\% 32$ & $\% 9$ & \%15 & $\% 12$ & $\% 8$ & $\% 10$ \\
\hline $\begin{array}{l}\text { 18. E-Kampüs sistemi web sayfasının kullanımının kolay } \\
\text { olduğunu düşünüyorum }\end{array}$ & $\% 60$ & $\% 55$ & $\% 61$ & $\% 63$ & $\% 57$ & $\% 30$ & $\% 27$ & $\% 26$ & $\% 24$ & $\% 33$ & $\% 10$ & \%18 & $\% 13$ & $\% 13$ & $\% 10$ \\
\hline $\begin{array}{l}\text { 19. Derslerde sunulan öğrenme materyallerini (pdf, ppt } \\
\text { vb.) kolaylıkla indirip, kaydedebilirim. }\end{array}$ & $\% 65$ & $\% 57$ & $\% 66$ & $\% 64$ & $\% 58$ & $\% 26$ & $\% 29$ & $\% 23$ & $\% 24$ & $\% 33$ & $\% 9$ & $\% 14$ & $\% 11$ & $\% 12$ & $\% 9$ \\
\hline
\end{tabular}

Not: G= Görme yetersizliği olanlar, İ= İşitme yetersizliği olanlar, $\mathrm{O}=$ Ortopedik yetersizliği olanlar, S= Süreğen hastalığı olanlar, D= Diğer yetersizlikler 


\section{Süreğen Hastalığa Sahip Olan Öğrencilerden Elde Edilen Bulgular}

Tablo 4'e göre süreğen hastalığı olan öğrencilerin \%73'ü başkasının yardımına ihtiyaç duymadan e-Kampüse ve derslere giriş yapabildiğini, \%68'i çevrimiçi sınavları tamamlayabildiğini, \%65'i e-kampüsteki duyuruların faydalı olduğunu, \%64'ü derslerdeki öğrenme materyallerini kolaylıkla indirip kaydedebildiğini, \%64'ü deneme sınavlarını tek başına yapabildiğini ve \%63'ü e-Kampüs sistemi web sayfasının kullanımının kolay olduğunu belirtmiştir. Süreğen hastalığı olan öğrencilerin \%24'ü eKampüste dersin öğretim elemanlarıyla iletişim kuramadığını, \%17'si ise AÖS destek biriminde e-kampüsle ilgili destek alamadığını belirtmiştir.

\section{Diğer Yetersizliklere Sahip Olan Öğrencilerden Elde Edilen Bulgular}

Tablo 4'e göre diğer yetersizlik grubundaki öğrencilerin \%59'u başkasına ihtiyaç duymadan e-Kampüse giriş yapılması, \%58'i e-Kampüs sistemindeki öğrenme materyallerinin kolaylıkla indirilip kaydedilmesi, \%58'si e-kampüste başkasına ihtiyaç duymadan derslere giriş yapılması, \%57'si e-Kampüs sistemi web sayfasının kullanımının kolay olması, \%57'si çevrimiçi sınavların başkasının yardımına ihtiyaç duymadan tamamlanması ve yine \%57'si e-kampüste faydalı duyurulan yapılması konularında "katılıyorum" şeklinde görüş bildirmiştir. Diğer yetersizlik grubundaki öğrencilerin katılmadığı görüşler arasında en sık belirtilen konular dersleri yürüten öğretim elemanlarıyla iletişim kurma (\%18) ve AÖS destek biriminden destek alma (\%19) şeklindedir.

\section{Tüm Yetersizlik Gruplarında En Çok Bildirilen Gelişmeye Açık Alanlar}

Önceki başlıklarda tüm yetersizlik grubuna ait öğrencilerin Engelsiz AÖF web sayfası ve e-Kampüse kullanıcı deneyimlerine ilişkin bulgular paylaşılmıştır. Bu doğrultuda tüm yetersizlik gruplarında en sı belirtilen "katılmıyorum" yanıtları Tablo 5'te özetlenmiştir.

Tablo 5'te her yetersizlik grubunun hem Engelsiz AÖF Web Sayfası kullanıcı deneyimi maddelerine hem de E-Kampüs Sistemi kullanıcı deneyimi maddelerine verdikleri olumsuz yanıtlar ("katılmıyorum") arasında en sık ifade edilen maddeler yer almaktadır. Buna göre yetersizlik türüne bakılmaksızın tüm özel gereksinimli öğrencilerin \%18'inden fazlası öğrenci işleri, çağrı merkezi ve AÖS destek birimleriyle kolaylıkla iletişim kuramadığını ifade etmişlerdir. Betimsel istatistiklere bakıldığında en yüksek yüzdenin \%30 ile ihtiyaç anında çağrı merkezine ulaşma ve \%27 ile e-Kampüs dersini yürüten öğretim elemanlarıyla iletişim kurma konusunda olumsuz görüş bildiren işitme yetersizliği olan öğrencilerde olduğu görülmektedir. 
Tablo 5

Açıöğretime Kayıtlı Özel Gereksinimli Öğrencilerin Engelsiz AÖF Web Sayfası ve EKampüs Sistemi Kullanımlarında En Fazla “Katılmıyorum” Yanıtı Gelen Maddeler

\begin{tabular}{|c|c|c|c|}
\hline MADDE & GRUP & $\begin{array}{l}\text { Engelsiz } \\
\text { AÖF }\end{array}$ & $\begin{array}{c}\text { E- } \\
\text { Kampüs }\end{array}$ \\
\hline \multirow{3}{*}{$\begin{array}{l}\text {-Kayıt süresince ihtiyaç duyduğum anlarda } \\
\text { Açıööğretim Sistemi öğrenci işleriyle } \\
\text { iletişim kurabiliyorum. (Engelsiz AÖF Web } \\
\text { Sayfası) }\end{array}$} & İşitme yetersizliği & $\% 22$ & $\% 27$ \\
\hline & Görme yetersizliği & $\% 21$ & $\% 18$ \\
\hline & Diğer yetersizlik & $\% 21$ & $\% 18$ \\
\hline \multirow{2}{*}{$\begin{array}{l}\text {-E-Kampüste dersleri yürüten öğretim } \\
\text { elemanlarıyla kolaylıkla iletişim } \\
\text { kuruyorum. (E-Kampüs Sistemi) }\end{array}$} & Süreğen hastalık & $\% 20$ & $\% 24$ \\
\hline & Ortopedik yetersizlik & $\% 19$ & $\% 22$ \\
\hline \multirow{5}{*}{$\begin{array}{l}\text { İhtiyaç duyduğum anlarda çağrı merkezine } \\
\text { ulaşabiliyorum. }\end{array}$} & İşitme yetersizliği & $\% 30$ & - \\
\hline & Ortopedik yetersizlik & $\% 24$ & - \\
\hline & Süreğen hastalık & $\% 22$ & - \\
\hline & Diğer yetersizlik & $\% 22$ & - \\
\hline & Görme yetersizliği & $\% 21$ & - \\
\hline \multirow{5}{*}{$\begin{array}{l}\text {-Engelsiz AÖF sistemiyle ilgili yardıma } \\
\text { ihtiyaç duyduğumda AÖS destek birimine } \\
\text { ulaşabiliyorum. } \\
\text {-E-Kampüs sisteminde sorun yaşadığımda } \\
\text { AÖS destek biriminden kolaylıkla destek } \\
\text { alabiliyorum. }\end{array}$} & İşitme yetersizliği & $\% 22$ & $\% 20$ \\
\hline & Ortopedik yetersizlik & $\% 19$ & $\% 19$ \\
\hline & Diğer yetersizlik & $\% 18$ & $\% 19$ \\
\hline & Görme yetersizliği & $\% 17$ & $\% 17$ \\
\hline & Süreğen hastalık & $\% 14$ & $\% 17$ \\
\hline \multirow{3}{*}{$\begin{array}{l}\text { AÖF kayıt koşullarının tüm yetersizlik } \\
\text { gruplarını kapsadığını düşünüyorum. }\end{array}$} & İşitme yetersizliği & $\% 19$ & - \\
\hline & Görme yetersizliği & $\% 18$ & - \\
\hline & Ortopedik yetersizlik & $\% 18$ & - \\
\hline \multirow{3}{*}{$\begin{array}{l}\text { Program tercihi yaparken tüm programlara } \\
\text { ilişkin bilgilere Engelsiz AÖF web } \\
\text { sayfasından kolaylıkla ulaşabiliyorum. }\end{array}$} & Diğer yetersizlikler & $\% 23$ & - \\
\hline & İşitme yetersizliği & $\% 21$ & - \\
\hline & Ortopedik yetersizlik & $\% 18$ & - \\
\hline \multirow{5}{*}{$\begin{array}{l}\text { E-Kampüste deneme sınavları için verilen } \\
\text { sürenin yeterli olduğunu düşünüyorum. }\end{array}$} & İşitme yetersizliği & - & $\% 19$ \\
\hline & Ortopedik yetersizlik & - & $\% 17$ \\
\hline & Diğer yetersizlik & - & $\% 14$ \\
\hline & Görme yetersizliği & - & $\% 14$ \\
\hline & Süreğen hastalık & - & $\% 13$ \\
\hline
\end{tabular}


Bunların yanı sıra AÖF kayıt koşullarının tüm yetersizlik gruplarını kapsaması görüşüne katılmadığını bildiren öğrencilerin büyük kısmının işitme, görme ve ortopedik yetersizliği olduğu görülmektedir. Engelsiz AÖF web sayfasından kolaylıkla tüm programlara erişebilme görüşüne katılmayan öğrencilerin çoğu ise işitme yetersizliği, ortopedik yetersizlik ve diğer yetersizlikler grubundadır. Bunların yanı sıra dikkat çeken bir diğer konu da e-Kampüs sisteminde deneme sınavlarının yeterli süre içermediğidir. $\mathrm{Bu}$ konuda özellikle işitme yetersizliği olan öğrenciler (\%19) olumsuz görüş bildirmiştir.

Özet olarak tüm yetersizlik gruplarındaki öğrencilerin Engelsiz AÖF web sayfası ve eKampüs sistemi kullanıcı deneyimlerinde iletişim desteği konusunda güçlük yaşandığı sonucuna ulaşılmıştır. Ayrıca en sık bildirilen konular arasında programa kayıt koşullarının kapsayıcılığının yeterli olmadığı ve web sayfasından tüm programlara erişimin kolay olmadığı, deneme sınavları için yeterli sürenin verilmediği konuları yer almiştır.

\section{Görüşmelerden Elde Edilen Bulgular}

Araştırmaya katılan 9513 özel gereksinimli öğrenci ile anket aracılığıyla Engelsiz AÖF web sayfası ve e-Kampüs sistemine ilişkin kullanıcı deneyimleri belirlenmiş ardından araştırma evreninden ölçüt örneklemeyle oluşturulan \%80 ve üzeri görme yetersizliği bulunan öğrenciler arasından gönüllü olarak seçilmiş 20 görme yetersizliği olan öğrenciye ulaşılmış ve yarı yapılandırılmış görüşmeler yapılmıştır. Görüşmelerin içerik analizi sonucunda nitel bulgular dört ana tema altında alt temalara ve kodlara ayrılmıştır. Buna göre görüşmelerden elde edilen bulgular Tablo 6'da özetlemiştir.

Tablo 6'da görüldüğü gibi görme yetersizliği olan öğrencilerle gerçekleştirilen yarı yapılandırılmış görüşmeler sonucunda ortaya çıkan temalar (1) Açıöğretim Sistemi ve Engelsiz AÖF ile ilgili görüşler, (2) e-kampüse ilişkin görüşler, (3) çağrı merkezi ve AÖS destek sistemiyle ilgili görüşler ve (4) gereksinim duyulan destekler ve öneriler şeklindedir. Açıöğretim Sistemi ve Engelsiz AÖF konusunda web sayfasının kullanımının kolay olduğu ifade edilirken sık belirtilen görüşlerden biri sistemin ek yazılımları çalıştırılmasında yaşanan güçlükler olmuştur. Bu konuda Berna Hanım "Evet bahsettiğim voice over programı bazen internet sitesinde çok erişilebilir olmayan her kısmı tam olarak okuyamayabiliyor", Doruk Bey "Jaws programı da nasıl diyeyim bende ki mi böyle tabela üzerindeki yazıları okuyamıyor. Normal hani renkli ya da kitap üzerindeki yazıları okuyamıyor sadece kitap içeriğini okuyor yani”, şeklinde görüş bildirmiştir. Ayrıca görme yetersizliği olan öğrenciler ara yüzle ilgili olarak mobil uygulamanın giriş ekranının kullanımında yaşadıkları bazı güçlükleri bildirmişlerdir. Berna Hanım "iOS uygulamasında da giriş yaparken Anadolu Üniversitesinde giriş yaparken giriş kısmını kullanıcı adı, e posta ve şifre kısmını okuyamıyor...", Pelin Hanım "Mobil uygulamadan girişte zorlanıyorum, giriş ekranı düzeltilirse çok iyi olur" şeklinde görüş belirtmiştir. Bunlara ek olarak bazı katılımcılar mobil uygulamaya giriş yapmakta zorlandıklarını ve bazı sesli kitapları açmakta güçlük yaşadıklarını ve kayıtlı derslerin videolarına erişemediklerini belirtmişlerdir. 
Tablo 6

Görüşmelerden Elde Edilen Bulgular

Temalar ve Alt Temalar

1) Açıöğretim Sistemi ve Engelsiz AÖF’e İlişskin Görüşler

Engelsiz AÖF Web Sayfasının Kolay Kullanımı

Açıköğretim Sistemi Uygulamasının Kullanımında Güçlükler

Ek yazımların çalıştırılmasında güçlükler

Mobil uygulama giriş ekranı kullanımında güçlükler

2) E-Kampüse İlişkin Görüşler

Olumlu Görüşler

Faydalı içeriklerin sunumu

Sistemin kolay kullanımı

Olumsuz Görüşler

Bazı derslerin sesli kitaplarının bulunmaması

Derslerin kayıtlı videolarına erişimde güçlükler

3) Çağrı Merkezi ve AÖS Destek Sistemiyle İlgili Görüşler

Olumlu Görüşler

Hızlı dönüş sağlanması

İlgi gösterilmesi

Olumsuz Görüşler

Çağrı merkezi veya AÖS desteğe erişimde güçlükler

4) Gereksinim Duyulan Destek ve Öneriler

Talep Edilen Destekler

Sesli kitapların insan sesiyle hazırlanması

Görme yetersizliği olanlara telefonla bildirim

Giriş sayfasında sesli yönlendirme

Ekran okuyucu programların sadeleştirilmesi

Derslerin sesli anlatımlarının arttırılması

PDF'lerin tüm sesli programlar tarafından okunabilmesi

Canlı derslere kolay erişim sağlanmEngelsizası

Web sayfasının sadeleştirilmesi: Tüm uygulamalara tek yerden girilmesi

Sınav esnasında yazıların büyütülebilmesi

Sınavlarda ek süre verilmesi

ÖnerilerDers içeriklerinin genişletilmesi

Ders seçimi sayfasına derslerin içeriğiyle ilgili özet bilgi eklenmesi 
E-Kampüs sisteminin kullanımına ilişkin olumlu düşüncelerde sistemin kolay kullanıldığı ve faydalı içeriklerin sunulduğu görüşü hakimdir. Olumsuz görüşlerde ise katılımcıların dördü bazı konuların sesli kitaplarının bulunmadığını ve bunlara ihtiyaç duyduklarını, ikisi ise kayıtlı ders videolarına erişim güçlüğü yaşadıklarını belirtmişlerdir.

Çağrı merkezi ve AÖS destek sistemiyle ilgili katılımcıların büyük kısmı hızlı dönüş sağlanması ve ilgi, alaka gösterilmesi şeklinde olumlu görüş bildirmiştir. Öte yandan nicel bulgularda sık belirtilen konulardan biri olarak görüşmelerde de görme yetersizliği olan öğrencilerin bazıları çağrı merkezine ve AÖS desteğe erişimde güçlük yaşadığını bildirmiştir. SMS ile bilgi verilen sınavlara ilişkin Gülru Hanım “...bu en son ki vizelerde sadece mesaj geldi ama hani mesela sınavınızın başlangıcı şu gün bitişi şu gün gibi bir bilgi daha iyi olabilir" şeklinde görüş bildirmiştir.

Görme yetersizliği olan öğrenciler Engelsiz AÖF web sayfası ve e-Kampüs kullanımında yaşadıkları bazı güçlükler doğrultusunda çeşitli desteklere gereksinim duyduklarını ifade etmişlerdir. Bu destekler şu şekilde özetlenebilir:

- Sesli kitapların mekanik seslendirme yerine insan sesiyle hazırlanması

- Sistemden gelecek mesaj ve duyurular için görme yetersizliği olan öğrencilere telefonla erişim sağlanması

- Giriş sayfasında kullanıcı adı, e-posta, şifre yazımında sesli yönlendirmeler kullanılması

- Ekran okuyucu programlarının imleçler yardımıyla yönlendirmelerinin belirginleştirilmesi, kullanımının sadeleştirilmesi,

- Derslerde yazılı metin ve içeriklerden ziyade sesli anlatım materyallerinin (sesli özet, sesli kitap) arttırılması,

- Özel gereksinimli öğrencilerin kullandıkları ek yazılımların tüm PDF’leri okuyabilmesi için ek yazılımlarla ilgili düzenlemelerin yapılması,

- Canlı derslere daha kolay erişim sağlanması için kullanıcı ara yüzünün sadeleştirilmesi,

- Web sayfasının sadeleştirilmesi ve tüm uygulamalara (Engelsiz AÖF, Anadolu Üniversitesi, e-Kampüs vb.) tek bir ana sayfadan giriş yapılması,

- Çevrimiçi sınavlarda yazıların büyütülebilmesi için gerekli düzenlemenin yapılması,

- Çevrimiçi sınavlarda ek süre verilmesi.

$\mathrm{Bu}$ desteklerin yanı sıra katılımcılar Açıköğretim Sisteminde özel gereksinimli öğrencilere yönelik ders içeriklerinin genişletilebileceğini ve ders seçim sayfasına derslerin içeriğiyle ilgili özet bilgiler eklenerek tanıtım yapılabileceğini belirtmişlerdir. 


\section{SONUÇ, TARTIŞMA VE ÖNERILER}

Araştırmanın nicel boyutunda anket aracılığıyla elde edilen bulgulara göre özel gereksinimli bireylerin yetersizlik türünden bağımsız olarak, düzenlemeler yapılmasını önerdiği konular; sıklıkla öğrenci işleri, çağrı merkezi ve AÖS destek birimleriyle iletişim, ihtiyaç anında çağrı merkezine ulaşım, e-Kampüs dersini yürüten öğretim elemanlarıyla iletişim olmuştur (Bkz. Tablo 5). Açık ve uzaktan öğrenme süreçlerinde öğrenenlerin bulundukları fiziksel uzaklıktan kaynaklı olarak yaşamış oldukları sosyal izolasyonu önleyebilmek için, öğrenenler ile süreç içinde sürekli olarak iletişim halinde olması gerektiği söylenebilir (Kılınç, 2021). Bu sayede, öğrenenlerin kendilerini öğrenme süreçlerinden izole etmesi de önlenebilir. Bu durumun yanı sıra görüşme bulgularında da çağrı merkezi ve AÖS desteğe erişim konularının ele alınması gerektiği görülmüştür. Bu noktada özel gereksinimli öğrencilerin hem Engelsiz AÖF hem eKampüs Sistemi kullanımında iletişim yollarının ele alınması gerektiği sonucuna ulaşılmıştır. Özel gereksinimli öğrenenlere yönelik olarak verilen hizmetler bağlamında ulaşılan bu sonuçlara benzer olarak Emiroğlu (2015), özel gereksinimli bireylerin bağlı bulundukları kurumlar kapsamında; kendilerini ifade edebilmek, yaşadıkları sorunları hızlı bir şekilde iletebilmek gibi iletişim konularında büyük bir gereksinim duyduklarını vurgulamıştır. Bir başka çalışmada Hamilton ve Keten (2011), bilgi kaynaklarına erişim sağlamanın ve bu kaynaklardan faydalanmanın özel gereksinimli bireylerin en fazla ihtiyaç duyduğu konuların başında olduğunu ifade etmiştir. Araştırmaların bulguları doğrultusunda iletişim kanallarının güçlendirilmesi, çağrı merkezine ve AÖS destek birimine içinde özel eğitim uzmanının da yer aldığı danışman ekiplerin kurulması, anında iletişim sağlayacak alternatif sistemlerin geliştirilmesi önerilebilir.

Öte yandan Tablo 5'te görüleceği gibi öğrenci işleriyle, AÖS destekle, çağrı merkeziyle ya da e-Kampüste ders veren öğretim elemanlarıyla kolay iletişim kurmada bazı noktalarda düzenlemelere gidilmesi gerektiğinin bildiren en yüksek frekansa sahip yetersizlik grubu, işitme yetersizliğidir. Bu durumun işitme yetersizliğinin doğası gereği dil ve iletişimde yaşadıkları güçlükten kaynaklanmış olabileceği düşünülmektedir. Dolayısıyla iletişim kanallarının geliştirilmesinde işitme yetersizliğine özel düzenlemelere ihtiyaç bulunmaktadır. Emiroğlu (2015) da işitme yetersizliği olan öğrenenler için gerekli olan yazılı iletişimin, kurumların Web sayfalarında bulunması gerektiğinin altını çizmiştir. Bununla birlikte Şahin-İzmirli, Dönmez ve Kabakçı-Yurdakul (2011) tarafından gerçekleștirilen bir diğer çalışmada, üniversite Web sayfaları incelenmiş ve bunun sonucunda genel anlamda özel gereksinimli bireylerin Web sayfalarında gezinebilmelerini kolaylaştırıcı özelliklerin sınırlı olduğu ifade edilmiştir. İşitme ve konuşmada yaşanan güçlüklerin önüne geçebilmek adına işitme yetersizliği olan öğrencilere özel yazılı canlı destek uygulaması, Engelsiz AÖF ana sayfası üzerinde kolay erişilebilir yazılı mesajlaşma bölümünün yer alması, çağrı merkezine yazılı erişimin sağlanması, otomatik mesaj kalıplarıyla kayıt haftası ve sınav dönemine özel yazılı bildirim seçeneklerinin oluşturulması önerilebilir. 
İletişim alanında olumsuz yanıt bildiren yüksek katılımcılı (Bkz. Tablo 5) bir diğer grup, görme yetersizliği olan öğrencilerdir. $\mathrm{Bu}$ durumun görme yetersizliği sebebiyle arayüzün kullanımında güçlük yaşanması ve iletişim kanallarına ulaşılamamasından kaynaklandığı düşünülmektedir. Görme yetersizliği olan bireylerin Web sitelerinde yaşadıkları sorunları inceleyen bir çalışmada bu sorunların giderilebilmesi için ekran okuyucu ve punto büyütücü programların kullanılması gerektiğini ifade edilmiştir (Hamilton ve Keten, 2011). Görmede dolayısıyla okumada güçlük yaşayan bu grup için Engelsiz AÖF web sayfasında sesli yönlendirmeler ile çağrı merkezi, AÖS destek ve öğrenci işleri bölümüne erişim sağlanması, bu bölüme erişim halinde ilgili iletişim numaralarının sesli olarak verilmesi, ekran okuyucuların kullanılması ve iletişim kanallarının büyük puntoyla, renlendirilerek yazılması yaşanan güçlüklerin önüne geçecektir.

Düzenlenmesi gereken bir diğer önemli konu ise Engelsiz AÖF web sayfasında programlara ilişkin bilgilere erişimdir. Özel gereksinimli bireyler, program tercihi yaparken web sayfası üzerinden tüm programlara ilişkin bilgilere erişmek istediklerini belirtmiştir. Ayrıca araştırmanın nitel aşamasında elde edilen bulgular, nicel bulgulara paralel olarak ders seçim sayfasında derslerin içeriklerine ilişkin özet bilgilerin yer alması yönündedir. Eğitimde açıklık ilkesi doğrultusunda tüm programların tüm öğrenciler için erişilebilir olması esastır (Ekren ve Kumtepe, 2018). Bu noktada Engelsiz AÖF ana sayfasında tüm programlara tek bağlantıdan erişim sağlayan bir sekme eklenmesi, sekme içerisinde her bir programa ilişkin tanıtıcı özet bilgilere yer verilmesi önerilmektedir.

Nicel aşama ve nitel aşamada ortak olarak belirtilen bir diğer konu ise sınav süreleridir. Anketten elde edilen bulgular, deneme sınavlarına ek süre verilmesi gerektiğini göstermektedir (Bkz. Tablo 5). Nitekim görüşmelerde de katılımcılar, sınavlara ek süre verilmesini gündeme getirmiştir. Açıöğretim çevrimiçi sınavları ülke genelinde yapılandırılan aynı anda gerçekleştirilen toplu sınavlar olduğu için süre değişikliği yerine özel gereksinimli bireylerin sınavları yetiştirememesi güçlügüne ilişkin soru sayısının azaltılması önerilebilir. Mevcut çevrimiçi sınav sisteminde 30 soru için 40 dakika süre verilmektedir. Pandemi öncesinde yapılan yüz yüze sınavlarda, sınav kitapçığındaki her bir ders için 20 soru yer almakta ve $30 \mathrm{dk}$ süre verilmekteydi. Dolayısıyla çalışmada belirtilen ek süre destek talebine ilişkin olarak çevrimiçi sınavlarda 40 dakika için 20 soru düzenlemesiyle bir başka deyişle soru sayısının azaltılmasıyla bu güçlüğe yönelik iyileştirme sağlanabilir. Çalışma kapsamında elde edilen bu sonuca benzer olarak, özel gereksinimli öğrencilerin sınavlarda yaşadıkları sorunlar üzerine gerçekleştirilen çalışmalarda, bu öğrencilerin sınavlarda ek süreye ihtiyaç duyduklarını ifade edilmiştir (Furat, 2012; Şenel, 2015). Dolayısıyla sınav sürecinde özel gereksinimli bireylere süre konusunda da yardım edilmesi gerektiği söylenebilir.

Görme yetersizliği olan öğrencilerle gerçekleştirilen görüşmelerde dile getirilen durumlar, bulgular başlığında görüleceği gibi Engelsiz AÖF web sayfası ve e-Kampüs 
sisteminin kullanıcı ara yüzüne erişim, bu sayfaların görme yetersizliğine özel ek yazılımları desteklemesi, sesli kitapların tamamlanması, Açıköğretim sistemi mobil uygulamasına giriş kısmının düzenlenmesi, ders materyallerinin ve sınav uygulamalarının tüm yetersizlik gruplarına göre uyarlanması konularından oluşmaktadır (Bkz. Tablo 6). Rosa ve Valentim'in (2020) yürüttügü çalışmada ise görme yetersizliği olan bireylerin ekran büyüklüğü, buton biçimleri, renk yoğunluğu gibi farklı tipolojik ögelerin geliştirilmesine yönelik gereksinimleri belirtilmiştir. Anadolu Üniversitesi e-Kampüs sisteminde görme yetersizliği olan bireyler için geliştirilen "Erişilebilirlik Menüsü" sözü edilen boyut, renk, biçim gibi ögelerini kullanıcıya özel uyarlamaktadır. Bu noktada araştırma bulgularında bu ögelere ilişkin vurgunun sadece çevrimiçi sınavlarda yazıların büyütülmesiyle sınırlı olması etkin şekilde kullanılan "Erişilebilirlik Menüsü" ile açılklanabilir. Öte yandan görme yetersizliği olan öğrencilerin kendi destek talepleri ve alanyazın doğrultusunda (Cho, 2021; Rosa ve Valentim, 2020; Yusril, 2020) bu durumların giderilmesine yönelik öneriler; tüm derslerin sesli kitaplarının oluşturulması ve mümkünse makine sesi yerine insan sesiyle kayıt sağlanması, hem Engelsiz AÖF hem de e-Kampüs sisteminde görme yetersizliği olan öğrencilere özel kullanıcı arayüzü tasarlanması, arayüzün sadeleştirilmesi, giriş ve ilgili bölüme erişimde sesli yönlendirmeler eklenmesi, çevrimiçi sınav uygulamalarında yazıların büyütülmesi ve ek süre verilmesi, son olarak sistemin, görme yetersizliği öğrencilerin kullandığı Voice Over, Jaws gibi ek yazılımlara uyumlu hale getirilmesi şeklinde listelenebilir.

Tüm bu sonuçlara paralel olarak ilgili alanyazında gerçekleştirilen çalışmalar (Bühler ve Fisseler, 2007; Petrie vd., 2006; Santos, Couchet ve Boticario, 2009; Okur ve Demir, 2019; Rosa ve Valentim, 2020; Schrepp vd, 2017; Yusril, 2020) özel gereksinimli bireylerin kullandıkları Web sitesi gibi sistemlerde kullanıcı deneyimlerine yer vermenin ve bu doğrultuda düzenlemeler yapmanın önemli bir gereksinim olduğu vurgulanmaktadır. Bu noktada, gerçekleştirilecek olan düzenlemeler sırasında evrensel tasarım ilkeleri ve kullanıcı merkezli tasarım ilkeleri doğrultusunda tasarımlar yapılması önerilebilir. Anadolu Üniversitesi özelinde gerçekleştirilen bu çalışma kapsamında özel gereksinimli öğrencilerin öğrenme sistemlerini kullanmaları sırasında elde ettikleri deneyimlere yer verilmesi sonucu elde edilen bulgular ışığında Engelsiz AÖF ve eKampüs sisteminde yaşanan güçlükler ortaya çıkarılmıştır. Bu doğrultuda gerekli görülen düzenlemeler gerçekleştirilerek sistemlerin iyileştirilmesi sağlanacaktır. $\mathrm{Bu}$ duruma paralel olarak Rosa ve Valentim (2020), gerçekleştirdikleri çalışma kapsamında kullanıcı deneyimlerinin, öğrenme sistemlerinin kalitesini artırabilmek için önemli bir unsur olduğunu vurgulamıştır. Bununla birlikte, özel gereksinimli bireyler açısından Web sitelerinin kullanılabilirlik durumlarının oldukça önemli bir nokta olduğu (King vd., 2005) göz önünde bulundurulduğunda, gerçekleştirilen bu çalışmayla birlikte ulusal düzlemde en fazla özel gereksinimli öğrenene sahip olan Anadolu Üniversitesi tarafından kullanılan öğrenme sistemlerinin daha verimli bir şekilde kullanılabileceği ifade edilebilir. Öğrenme sistemlerinin daha kullanılabilir olması, özel gereksinimli öğrenenlerin daha zengin öğrenme deneyimleri yaşayabilmelerini de mümkün 
kılacaktır. Bunun yanı sıra, özel gereksinimli öğrenenlerin kullandıkları öğrenme sistemlerinin kullanılabilirlik durumlarının artması etkililik, verimlilik ve memnuniyet unsurlarını da beraberinde getirecektir (ISO, 2000). Özel gereksinimli öğrenci sayısı bakımından öncü olan Anadolu Üniversitesi Açıöğretim Sisteminde yürütülen bu çalışmaya dayalı elde edilen bulguların, diğer açık ve uzaktan öğrenme faaliyeti yürüten yükseköğretim kurumları için oldukça değerli çıktılar sağlayacağı düşünülmektedir.

\section{Kaynaklar}

Anderson, G. (1990). Fundamentals of educational research. Bristol: The Falmer Press.

Baird, D. E. ve Fisher, M. (2005). Neomillennial user experience design strategies: Utilizing social networking media to support "always on" learning styles. Journal of Educational Technology Systems, 34(1), 5-32.

Boeije, H. (2010). Analysis in qualitative research. SAGE Publication.

Bozkurt-Sani, S. (2017). Özel eğitimde dijital destek: Yardımcı teknolojiler. Açıköğretim Uygulamaları ve Araştırmaları Dergisi, 3(2), 37-60.

Bühler, C. ve Fisseler, B. (2007). Accessible e-learning and educational technology-extending learning opportunities for people with disabilities. Conference ICL2007, September 26 -28, 2007, Villach, Austria.

Büyüköztürk, Ş. (2005). Anket geliştirme. Türk Eğitim Bilimleri Dergisi, 3(2), 133-151.

Carneiro, L., Rebelo, F., Filgueiras, E. ve Noriega, P. (2015). Usability and user experience of technical aids for people with disabilities? A preliminary study with a wheelchair. Procedia Manufacturing, 3, 6068-6074.

Chmiliar, l. (2010). Multiple-case designs. In A. J. Mills, G. Eurepas \& E. Wiebe (Eds.), Encyclopedia of case study research (pp 582-583). USA: SAGE Publications.

Cho, J. D. (2021). A study of multi-sensory experience and color recognition in visual arts appreciation of people with visual impairment. Electronics, 10(4), 470-507.

Cooper, M., Colwell, C. ve Jelfs, A. (2007). Embedding accessibility and usability: considerations for e-learning research and development projects. ALT-J, 15(3), 231-245.

Creswell, J. W. (2014). Research design: Qualitative, quantitative, and mixed methods approach. (4th Edition). SAGE Publications.

Demetriadis, S. ve Pombortsis, A. (2007). E-lectures for flexible learning: A study on their learning efficiency. Educational Technology \& Society, 10(2), 147-157.

Durmuş, S. ve Çağıltay, K. (2012). Kamu kurumu web siteleri ve kullanılabilirlik. M. Z. Sobacı ve M. Yıldız (Ed.) E-devlet kamu yönetimi ve teknoloji ilişkisinde güncel gelişmeler (s. 293-322.).

Edyburn, D. L. (2001). Models, theories, and frameworks: Contributions to understanding special education technology. Special Education Technology Practice, 4(2), 16-24.

Ekren, G. ve Kumtepe, E. G. (2018). Yükseköğrenim düzeyinde uzaktan eğitimde "açıklık" kavramına yönelik içerik analizi. Açıö̈ğretim Uygulamaları ve Araştırmaları Dergisi, 4(2), 112-128. 
Emiroğlu, B. G. (2015). Üniversitelerin engelli destek ofislerinin web sayfalarının erişilebilirlikleri. Journal of Educational Sciences \& Practices, 14(27), 43-55.

Emre, İ. E., Akadal, E. ve Gülseçen, S. (2018). Örgün ve uzaktan eğitim öğrencileri için kullanılabilirlik araştırması: Marmara Üniversitesi web sitesi. Uluslararası Yönetim Biliş̧im Sistemleri ve Bilgisayar Bilimleri Dergisi, 2(1), 12-22.

Erlandson, D. A., Harris, E. L., Skipper, B. L. ve Allen, S. D. (1993). Doing naturalistic inquiry: A guide to methods. SAGE Publication.

Furat, E. (2012). Görme engelli öğrencilerin üniversite giriş sınavında karşslaștığı sorunlar ve çözüm önerileri. III. Eğitimde ve Psikolojide Ölçme ve Değerlendirme Kongresi. Abant İzzet Baysal Üniversitesi. Bolu.

Guba, E. G. ve Lincoln, Y. S. (1989). Fourth generation evaluation. SAGE Publication.

Güler, E. (2018). Açık ve uzaktan öğrenme ortamlarında esneklik. Açıköğretim Uygulamaları ve Araştırmaları Dergisi, 4(3), 75-95.

Hamilton, D. ve Keten, B. (2011). Görme Engelli Kullanıcılar İçin Erişilebilir Kütüphaneler: Kütüphanecilere Yönelik Pratik Öneriler. Türk Kütüphaneciliği, 25(4), 509-518.

Hassenzahl, M. (2013). User experience and experience design. The encyclopedia of humancomputer interaction, 2. Erişim adresi: https://www.researchgate.net/profile/MarcHassenzahl/publication/259823352_User_Experience_and_Experience_Design/links/56a7 352d08ae997e22bbc807/User-Experience-and-Experience-Design.pdf

Henry, S. L., Abou-Zahra, S. ve Brewer, J. (2014, April). The role of accessibility in a universal web. In Proceedings of the 11th Web for all Conference. MIT Open Access Articles.

Heward, W. L., Alber, S. R. ve Konrad, M. (2006). Exceptional children: An introduction to special education. Pearson Education/Merrill/Prentice Hall.

International Standards Organization (ISO): Standard 924 (2000). Ergonomic Requirements for Office Work with Visual Display Terminals. ISO, Geneva (1992-2000)

Kılınç, H. (2021). Opinions of Field Experts on Practices That Will Increase the Motivation Levels of Learners During the COVID-19 Pandemic Process. In Handbook of Research on Emerging Pedagogies for the Future of Education: Trauma-Informed, Care, and Pandemic Pedagogy (pp. 191-208). IGI Global.

King, A., Evans, D. G. ve Blenkhorn, P. (2005). The evaluation of a web browser for blind people. In Pruski, A., Knops, H. (Eds.) Assistive Technology: From Virtuality to Reality (pp. 637-641). IOS Press, Amsterdam.

Kuniavsky, M. (2010). Smart things: ubiquitous computing user experience design. Elsevier.

Küçükönder, N. ve Kır, İ. (2014). Uzaktan eğitim uygulamalarında açık kaynak kodlu öğrenme yönetim sistemlerinin yeniden yapılandırılmasının incelenmesi. Kahramanmaraş Sütçü İmam Üniversitesi Sosyal Bilimler Dergisi, 13(1), 295-304.

Lee, M., Han, S. H., Kim, H. K. ve Bang, H. (2015). Identifying user experience elements for people with disabilities. Proceedings of the 8th International Conference on Advances in ComputerHuman Interactions, Pohang, Korea. Access Adress: https://citeseerx.ist.psu.edu/viewdoc/download?doi=10.1.1.681.7575\&rep=rep1\&type=p df

Merriam, S. B. (2013). Nitel araştırma desen ve uygulama için bir rehber. (Çev: S. Turan). Ankara: Nobel Akademik Yayıncılık. 
Mills, G. E. ve Gay, L. R. (2016). Educational research competencies for analysis and applications. (11th Edition). Pearson.

Miles, M. B., Huberman A., M., \& Saldana, J. (2014). Qualitative data analysis: A methods sourcebook. (3rd Edition). SAGE Publication.

Mutlu, M. E. (2015). e-Öğrenme standartlarında yeni yönelimler. Açıöğgretim Uygulamaları ve Araştırmaları Dergisi, 1(4), 8-35.

Okur, M. R. ve Demir, M. (2019). Görme engelli öğrenenlerin eğitim yaşantısında karşılaştıkları sorunların belirlenmesi, açı ve uzaktan öğrenme alanı için çözüm yolları geliştirilmesi. Açıköğretim Uygulamaları ve Araştırmaları Dergisi, 5(2), 49-62.

Özarslan, Y. (2016). Kullanıcı deneyimi ve tasarımının önemi. H. Çalışkan ve M. R. Okur (Editörler), Kullanıcı deneyimi tasarımı (s. 2-17). Anadolu Üniversitesi Yayınları.

Özgüç, C. S. ve Cavkaytar, A. (2014). Teacher use of instructional technology in a special education school for students with intellectual disabilities: A Case Study. Turkish Online Journal of Qualitative Inquiry, 5(1), 51-65.

Park, K., Goh, T. ve So, H. J. (2014). Toward accessible mobile application design: developing mobile application accessibility guidelines for people with visual impairment. 한국 $\mathrm{HCI}$ 학회 학술대회, 31-38.

Petrie, H., Hamilton, F., King, N. ve Pavan, P. (2006, April). Remote usability evaluations with disabled people. In Proceedings of the SIGCHI conference on Human Factors in computing systems (pp. 1133-1141). Montreal, Canada. Access Adress: https://dl.acm.org/doi/abs/10.1145/1124772.1124942

Rosa, J. R. D. S. ve Valentim, N. M. C. (2020, October). Accessibility, usability and user experience design for visually impaired people: a systematic mapping study. In Proceedings of the 19th Brazilian Symposium on Human Factors in Computing Systems (pp. 1-10). Access Adress: https://dl.acm.org/doi/abs/10.1145/3424953.3426626

Santos, O. C., Couchet, J. ve Boticario, J. G. (2009, July). Personalized e-learning and e-mentoring through user modelling and dynamic recommendations for the inclusion of disabled at work and education. In Ninth IEEE International Conference on Advanced Learning Technologies (pp. 514-518), IEEE. Madrid, Spain. Access Adress: https://ieeexplore.ieee.org/document/5194291

Schrepp, M., Cota, M. P., Gonçalves, R., Hinderks, A. ve Thomaschewski, J. (2017). Adaption of user experience questionnaires for different user groups. Universal Access in the Information Society, 16(3), 629-640.

Sönmez, H. (2016). Engelli öğrencilerin sayısal ve sembol içerikli bir dersteki başarılarının incelenmesi: Anadolu Üniversitesi Açıöŏgretim Sistemi örneği. Açıköğretim Uygulamaları ve Araştırmaları Dergisi, 2(4), 8-21.

Sözer, B., Özdamar, N. ve Pilanci, H. (2020). Yabancı dil öğrenimi için hazırlanan e-öğrenme ortamlarına ilişkin kullanılabilirlik araştırmalarının incelenmesi. Açıöğretim Uygulamaları ve Araştırmaları Dergisi, 6(4), 174-207.

Şahin-İzmirli, Ö., Dönmez, O. ve Kabakçı-Yurdakul, I. (2011). Üniversite Web Sayfalarının Gezinim Kolaylaştırıcıları Açısından İncelenmesi: Türkiye Örneklemi. 5. Uluslararası Bilgisayar ve Öğretim Teknolojileri Sempozyumu. Frrat Üniversitesi, Elazığ. 
Şenel, S. (2015). Görme engelli öğrencilerin üniversite giriş sınavı deneyimleri. Hacettepe Journal of Educational Research, 1(1), 1-17.

Tanyeri, U. ve Tüfekçi, A. (2010, Kasım). Bir yükseköğretim uzaktan eğitim programının görme engellilerin kullanımı açısından değerlendirilmesi: GÜUEP örneği. In International Conference on New Trends in Education and Their Implications Antalya, Turkey. Access Adress: http://www.iconte.org/FileUpload/ks59689/File/254.pdf

Yıldırım, A. ve Şimşek, H. (2013). Sosyal bilimlerde nitel araştırma yöntemleri. (9. Baskı). Ankara: Seçkin Yayıncılık.

YÖK (2021). Yükseköğretim Bilgi Yönetim Sistemi. Engelli Öğrenci Sayıları Raporu. Erişim Adresi: https://istatistik.yok.gov.tr/

Yusril, A. N. (2020). E-accessibility analysis in user experience for people with disabilities. Indonesian Journal of Disability Studies, 7(1), 107-109. 
Bu çalışma için etik kurul izni 03/11/2020 tarih ve 60323 protokol sayılı Anadolu Üniversitesi Sosyal ve Beşeri Bilimler Bilimsel Araștırma ve Yayın Etiği Kurulu'ndan alınmıștır.

\section{Araştırmacıların Makaleye Katkı Oranı Beyanı:}

1. yazar katkı oranı: $\% 35$

2. yazar katkı oranı: $\% 35$

3. yazar katkı oranı: $\% 30$

Çıkar Çatışması Beyanı:

Yok.

Finansal Destek veya Teşekkür Beyanı

$\mathrm{Bu}$ çalıșma için herhangi bir kurumdan finansal destek alınmamıștır. 